\title{
Morphological variability and genetic diversity of Aman rice germplasm of Bangladesh cultivated in Mymensingh region
}

\author{
Fahmida Reza Emi ${ }^{1}$, Hadisa Khatun ${ }^{1}$, Fahmina Yasmine ${ }^{2}$, Ahmed Khairul Hasan ${ }^{1 *}$ \& Mohammad \\ Anwar Hossain ${ }^{3 *}$ \\ ${ }^{1}$ Department of Agronomy, Bangladesh Agricultural University, Mymensingh-2202, Bangladesh \\ ${ }^{2}$ Bangladesh Institute of Nuclear Agriculture, Mymensingh, Bangladesh \\ ${ }^{3}$ Department of Genetics and Plant Breeding, Bangladesh Agricultural University, Mymensingh-2202, Bangladesh \\ *Email: akhasan@bau.edu.bd; anwargpb@bau.edu.bd
}

\section{ARTICLE HISTORY}

Received: 08 June 2021

Accepted: 21 September 2021

Available online: 11 November 2021

\section{KEYWORDS}

Oryza sativa

Variability

Yield and related traits

Correlation

Path co-efficient

Heritability

Cluster analysis

\section{ABSTRACT}

Thirty-one Aman rice germplasm were evaluated to assess their morphological variability and genetic diversity considering ten quantitative and thirty one qualitative traits at the field experimental plot of Bangladesh Institute of Nuclear Agriculture, Mymensingh, following randomized complete block design. The germplasm showed significant differences for all the studied traits. The highest grain yield/plant was recorded in Sentu-16 whereas the lowest was found in Gaindha. The genotypic coefficient of variation (GCV) was lower than those of the corresponding phenotypic coefficient of variation (PCV) for all the traits. High PCV and GCV along with heritability, genetic advance (GA) and GA in percentage of mean were recorded for number of filled grains/panicle and number of unfilled grains/panicle. Grain yield/plant had positively significant correlation with plant height, number of total tillers/hill, number of effective tillers/hill, number of filled grains/panicle and thousand grain weight. Path co-efficient analysis suggested that grain yield/plant had positive direct effect in association with days to fifty percent flowering, number of effective tillers/hill, panicle length, number of filled grains/panicle and thousand grain weight. Principal component analysis revealed that the first three components accounted for $79.57 \%$ of cumulative variance. Cluster analyses were revealed that the studied rice germplasm organized into five clusters based on $D^{2}$ values where maximum intercluster distance was observed between cluster II and V. Qualitative characterization by distinctness, uniformity and stability test revealed that a wide range of variation was observed among the genotypes. Therefore, this study would be useful for breeders to choose and identify the revival and preservation of beneficial genes for crop improvement.

\section{Introduction}

Rice (Oryza sativa L.) is popularly called as 'global grain'. It is the staple food of about 156 million people of Bangladesh (1) which constitutes $95 \%$ of food grain production in the country. It is the easiest source of food and commodity of significance for the people of Bangladesh (2). It belongs to the family Gramineae. The amount of rice grown in Asia is about $90 \%$ of the world's rice which alone covers the food demand for about $60 \%$ population of the world (3). Bangladesh ranks fourth among the 114 rice growing countries of the world with the production of 52.3 million metric tonnes whereas China is the first with the production of 211.09 million metric tonnes (4). As rice plays a very important role in traditional diets and in the livelihood of people, it earns a special position in many nations. Three types of rice grown in
Bangladesh, viz., Aus, transplanted (T.) Aman, broadcast (B.) Aman and Boro depend on the wide environmental diversity which results from considerable variation in topographic and seasonal components. Land used for cultivating Aus, T. Aman and Boro season is 1.08, 4.86 and 5.68 million ha, respectively (4). Although the area under Aman rice is increased, the area for cultivation of local varieties is not increased due to its low yielding ability. Out of 5.68 million ha, only 0.94 million ha of land are used for cultivation of local varieties (5). As a result, the local varieties have been disappeared day by day.

Local germplasm of Aman rice plays an indispensable role in the local food security as well as sustainable development of agriculture (6) as germplasm provides adaptable genes for the changing environment and inclusion of these genes from landraces can ensure expected grain production.

(c) Emi et al (2021). This is an open-access article distributed under the terms of the Creative Commons Attribution License, which permits unrestricted use, distribution and reproduction in any medium, provided the original author and source are credited (https://creativecommons.org/licenses/by/4.0/). 
Many of the local varieties adapting in different parts of the country have very good quality, fineness, aroma, taste and high protein content (7). These also include sources for simply inherited resistance or tolerance against different biotic and abiotic stresses and provide complex traits for further improvement of grain quality and yield. So, the conservation of germplasm of local Aman rice varieties is very important. On the other hand, food is one of the security problems faced by the world in the 21st century. Among all food items, the significance of rice is supreme. The global rice demand will be 880 million tonnes in 2025 which is about $70 \%$ more than present production (8). In order to meet up the demand, two ways can be effective: expanding the rice growing area and increasing productivity or both (9). As there is no possibility of increasing cultivated area, development of high yielding varieties is the only option to increase the yield of Aman rice.

The future strategies in the improvement of rice largely depend on the availability of genetic resources and their effective utilization. At present, varietal identification for rice are primarily based on morphological and physiological parameters. During the development of varieties, the plant breeders who uses several techniques for creating genetic variation and selecting from within that variation mainly uses the superior plants after final selection (10). Parental genotypes from random populations are selected based on the information about genetic diversity. Besides genetic diversity, crop yield not only depends on the different yield contributing traits but also on the factors involved about environment. In case of rice, higher yield also depends on the higher number of effective tillers/hill, number of filled grains/panicle and 1000-grain weight (11). These traits are also correlated among themselves. The magnitude of genetic variability like as, phenotypic and genotypic variances, phenotypic coefficient of variation (PCV) and genotypic coefficient of variation (GCV), broad sense heritability, genetic gain (GA) is highly responsible for the genetic improvement of any crop based on which the breeding methods are constructed for its additional improvement. The extent of variability is measured by GCV and PCV. Correlation analysis is used to determine the association among the different traits (12). Principal component analysis (PCA) marks out the plant characters that provide the most in creating variation within a group of entries. On the other hand, the relationships between yield and yield contributing traits can be analyzed through path-coefficient (13) which explains the real causes of relationship. The above tools are found to be useful for proper characterization in further breeding program. Besides genetic characterization, qualitative characterization of Aman rice germplasm is essential for utilizing the appropriate attribute based donors for further study and also crucial to the present era for protecting unique rice. Plant characterization has been effectively used in searching out appropriate attributes among individual genotypes which is possible through distinctness, uniformity and stability (DUS) test (14).

Elucidation of morphological and genetic characterization and assessment of diversity is very crucial for future varietal improvement. There is no comprehensive report regarding the morphological and genetic variability and diversity of cultivated Aman rice germplasm of Mymensingh region. Lack of access to phenotype information is still seen as a limiting factor for the use of plant genetic resources. Therefore, the present study was conducted to characterize Aman rice germplasm based on morphological traits, to assess the nature and magnitude of genetic diversity, to study the relationship, heritability and genetic advances of yield and yield contributing traits and also to identify the suitable traits for varietal improvement.

\section{Materials and Methods}

\section{Plant materials, exploratory site and design}

The experiment was set up at the exploratory Farm of BINA, Mymensingh following randomized complete block design (RCBD) with three replications. Thirtyone rice genotypes (1.Gaindha, 2.Purabinni, 3.Fulkainja, 4.Rupashail, 5. Leda binni, 6.Biroi, 7.Chapal, 8.Sentu-15, 9.Sentu-19, 10.Lalchinishail, 11.Dudhbinni, 12.Champamashuri, 13.Chotosornolota, 14.Motamorang, 15.Pairjaat, 16.Sentu gold, 17.Markabinni, 18.Bishalibinni, 19.Goatibinni, 20.Shongbinni, 21.Sentu-18, 22.Fullota, 23.Mery gold, 24.Lalmatia, 25.Chapal-2, 26.Sentu-6, 27.Sentushail, 28.Sentu-17, 29.Sentu-16, 30.Ranishail and 31. Sentu-5) was used as plant materials which were collected from different places of Mymensingh region. The unit plot size was $2 \mathrm{~m} \times 3 \mathrm{~m}$. Twenty-five days old seedlings were used for transplanting @ one seedling hill ${ }^{-1}$ with the space of $15 \mathrm{~cm} \times 20 \mathrm{~cm}$. Recommended doses of fertilizers and manures were applied to the soil. Other intercultural operations were done whenever necessary.

\section{Data recording}

Five plants from each germplasm were selected randomly for data collection on different quantitative traits viz. plant height, days to $50 \%$ flowering, days to maturity, total tillers/hill, effective tillers/hill, panicle length, filled grains/panicle, unfilled grains/panicle, 1000-grain weight and yield/plant. Qualitative traits were collected in terms of blade pubescence, blade color, leaf sheath: anthocyanin color, basal leaf sheath color, leaf angle, flag leaf angle, ligule color, ligule shape, collar color, auricle color, culm anthocyanin color, culm angle, internode color, culm strength, panicle type, secondary branching, panicle exertion, axis, shattering, threshability, awn: distribution, awn color, apiculus color, stigma color, lemma and palea color, lemma and palea pubescence, sterile lemma color, seed coat color, endosperm type and decorticated grain: scent.

\section{Statistical analysis}

Statistical analysis was done for the data on different quantitative traits by using MINITAB ${ }^{\circledR} 17$ statistical software packages following a RCBD design. Estimation of the genotypic variance (GV) and phenotypic variance (PV), broad sense heritability (\%), GA was done following the standard formulae (15); GCV and PCV values were calculated (16); GA (\%) was also analyzed based on the formula (17).Transformed 
uncorrelated means of characters were used to calculate the Mahalanobis distance $\left(D^{2}\right)$ values (18). Pearson correlation matrix, path analysis, PCA and clustering were also performed using statistical software R, version 3.3.2.

\section{Results and Discussion}

Evaluation of performance of the studied rice germplasm for yield contributing traits

The differences among the germplasm for all the studied traits were highly significant $(p<0.01)$ (Table 1) which is an indication of genetic diversity of the germplasm. There are reports on highly significant no. of total tillers/hill $(27,28)$; for no. of effective tillers/hill $(24,29)$; for grain yield/plant $(30,31)$.

In this study, Ranishail was the tallest $(134.67 \mathrm{~cm})$ among the rice germplasm and Lalmatia $(71.33 \mathrm{~cm}$ ) was the shortest one. These variations in plant height are mostly due to different genetic makeup of the germplasm. In this investigation, it was found that Shongbinni was the late flowering (118 days) germplasm and Sentu-5 was the earliest (97.67 days) flowering one because of the influence of genetic inheritance and availability of nutrient content in soil. In case of maturity, Sentu-17 required the shortest time for maturity whereas Gaindha, Mery gold and Ranishail were the late maturing genotype. Days to maturity ranged from 135.33 to 151.33 days. The

Table 1. Mean performance of the studied rice genotypes for yield and yield attributing traits

\begin{tabular}{|c|c|c|c|c|c|c|c|c|c|c|}
\hline Variety & PH(cm) & DFF & DM & TTH (no.) & ET (no.) & PL (cm) & FGP(no.) & UGP(no.) & TGW (g) & GYP(g) \\
\hline Gaindha & $90.50 \mathrm{mn}$ & 108.67ef & 151.33a & $14.67 \mathrm{bc}$ & $8.500 \mathrm{p}$ & $28.83 a$ & $70.03 p$ & $62.22 \mathrm{~b}$ & $9.38 \mathrm{v}$ & $4.91 \mathrm{j}$ \\
\hline Purabinni & $72.60 q$ & 109.00ef & 149.33bc & 16.00ab & $10.33 \mathrm{k}$ & $25.17 \mathrm{c}-\mathrm{g}$ & 100.280 & $9.11 \mathrm{u}$ & $14.16 \mathrm{~s}$ & $6.87 \mathrm{hi}$ \\
\hline Fulkainja & $130.20 \mathrm{ab}$ & $113.33 c$ & $150.67 \mathrm{ab}$ & $13.67 \mathrm{c}$ & $13.33 \mathrm{e}$ & $24.17 \mathrm{e}-\mathrm{i}$ & $198.00 \mathrm{ef}$ & $19.33 n-q$ & $28.13 \mathrm{~b}$ & $8.96 \mathrm{~b}-\mathrm{d}$ \\
\hline Rupashail & $132.33 a$ & $107.67 \mathrm{e}-\mathrm{g}$ & $150.33 a b$ & $14.67 \mathrm{bc}$ & $14.67 \mathrm{c}$ & $22.33 i$ & $220.78 b$ & $44.37 \mathrm{de}$ & $25.77 d$ & $9.83 a b$ \\
\hline Leda binni & 115.63d-f & $117.67 \mathrm{a}$ & $150.00 \mathrm{a}-\mathrm{c}$ & $17.67 a$ & 13.50de & 22.67hi & $212.62 \mathrm{~cd}$ & $20.11 m-p$ & $20.33 \mathrm{ij}$ & $8.67 \mathrm{c}-\mathrm{f}$ \\
\hline Biroi & $117.73 \mathrm{c}-\mathrm{e}$ & $113.33 c$ & $146.00 \mathrm{e}$ & $14 \mathrm{bc}$ & 12.33gh & $25.00 \mathrm{c}-\mathrm{g}$ & $188.77 \mathrm{~g}$ & $22.78 \mathrm{j}-\mathrm{m}$ & $20.40 \mathrm{i}$ & $8.67 c-f$ \\
\hline Chapal & $120.07 \mathrm{~cd}$ & $107.67 \mathrm{e}-\mathrm{g}$ & $148.33 \mathrm{~cd}$ & $15 \mathrm{~b}$ & $14.00 \mathrm{~d}$ & $24.83 \mathrm{~d}-\mathrm{h}$ & $170.04 \mathrm{~h}-\mathrm{j}$ & 23.55i-l & $20.34 \mathrm{ij}$ & $8.83 c-e$ \\
\hline Sentu-15 & 112.67f-h & $104.67 \mathrm{~h}-\mathrm{i}$ & 145.33ef & 16.33ab & $15.00 \mathrm{c}$ & $24.83 \mathrm{~d}-\mathrm{h}$ & $185.78 \mathrm{~g}$ & $15.22 \mathrm{r}-\mathrm{t}$ & $26.54 \mathrm{c}$ & $9.50 \mathrm{a}-\mathrm{c}$ \\
\hline Sentu-19 & $115.07 \mathrm{e}-\mathrm{g}$ & 105.33g-i & $135.67 \mathrm{k}$ & $16.00 \mathrm{ab}$ & $15.67 \mathrm{~b}$ & $25.50 \mathrm{~b}-\mathrm{f}$ & $190.76 \mathrm{fg}$ & 20.67l-p & $21.50 \mathrm{~g}$ & $9.83 a b$ \\
\hline Lalchinishail & $86.50 \mathrm{no}$ & 104.67h-i & $149.33 \mathrm{bc}$ & $16.00 \mathrm{ab}$ & 10.00ki & $27.17 a-c$ & $147.891 \mathrm{~lm}$ & $22.33 \mathrm{j}-\mathrm{n}$ & $15.67 p$ & 7.67gh \\
\hline Dudhbinni & $118.00 \mathrm{c}-\mathrm{e}$ & $112.33 \mathrm{c}-\mathrm{d}$ & $145.67 \mathrm{ef}$ & $14.67 \mathrm{bc}$ & $12.67 \mathrm{fg}$ & $25.00 \mathrm{c}-\mathrm{g}$ & $186.11 \mathrm{~g}$ & $19.000-q$ & $20.80 \mathrm{~h}$ & $8.67 c-f$ \\
\hline Champamashuri & $90.83 \mathrm{mn}$ & $102.67 \mathrm{i}$ & 139.33hi & $14.33 \mathrm{bc}$ & $13.00 \mathrm{ef}$ & $23.07 g-i$ & $198.78 \mathrm{e}$ & $39.22 \mathrm{f}$ & $22.07 \mathrm{f}$ & $9.00 \mathrm{~b}-\mathrm{d}$ \\
\hline Chotosornolota & 84.32op & $107.67 \mathrm{e}-\mathrm{g}$ & $137.00 \mathrm{jk}$ & $10.33 d$ & 9.00no & $22.50 \mathrm{i}$ & $148.11 \mathrm{~lm}$ & $27.00 \mathrm{~h}$ & $15.00 q$ & $7.67 \mathrm{gh}$ \\
\hline Motamorang & $110.67 \mathrm{~g}-\mathrm{i}$ & $109.00 \mathrm{ef}$ & 149.67 a-c & $12.33 \mathrm{c}$ & $10.33 \mathrm{k}$ & $22.50 \mathrm{i}$ & $217.60 \mathrm{~b}-\mathrm{d}$ & $10.33 \mathrm{u}$ & $17.00 \mathrm{n}$ & $8.00 \mathrm{e}-\mathrm{g}$ \\
\hline Pairjaat & 82.57 op & $110.33 \mathrm{de}$ & $145.33 \mathrm{ef}$ & $8.67 \mathrm{e}$ & $8.00 \mathrm{p}$ & $24.92 \mathrm{c}-\mathrm{h}$ & $137.33 n$ & 20.66 l-p & $11.80 \mathrm{t}$ & $7.33 \mathrm{gh}$ \\
\hline Sentu gold & 84.33 op & $108.67 \mathrm{ef}$ & 140.33 gh & $15.3 \mathrm{~b}$ & $11.00 \mathrm{j}$ & $24.42 \mathrm{~d}-\mathrm{i}$ & $155.33 \mathrm{kl}$ & $35.67 \mathrm{~g}$ & $18.00 \mathrm{~m}$ & $8.17 \mathrm{~d}-\mathrm{g}$ \\
\hline Markabinni & 118.30 c-e & $110.33 \mathrm{de}$ & $151.00 \mathrm{ab}$ & $12.67 \mathrm{c}$ & $11.00 \mathrm{j}$ & $24.83 \mathrm{~d}-\mathrm{h}$ & $150.22 \mathrm{kl}$ & $21.56 \mathrm{k}-\mathrm{o}$ & $17.94 \mathrm{~m}$ & $8.17 \mathrm{~d}-\mathrm{g}$ \\
\hline Bishalibinni & $127.50 \mathrm{~b}$ & $116.67 \mathrm{ab}$ & 150.00 a-c & $16.00 \mathrm{ab}$ & $15.67 \mathrm{~b}$ & $24.00 \mathrm{e}-\mathrm{i}$ & $220.02 \mathrm{bc}$ & $24.67 \mathrm{~h}-\mathrm{k}$ & $31.42 \mathrm{a}$ & $9.83 \mathrm{ab}$ \\
\hline Goatibinni & $106.30 \mathrm{ij}$ & $114.00 \mathrm{bc}$ & $148.33 \mathrm{~cd}$ & $14.67 \mathrm{bc}$ & $12.00 \mathrm{hi}$ & $24.33 \mathrm{e}-\mathrm{i}$ & $171.42 \mathrm{~h}-\mathrm{j}$ & $25.44 \mathrm{~h}-\mathrm{j}$ & $21.77 \mathrm{fg}$ & $8.83 \mathrm{c}-\mathrm{e}$ \\
\hline Shongbinni & $112.67 \mathrm{f}-\mathrm{h}$ & $118.00 \mathrm{a}$ & $149.33 \mathrm{bc}$ & $11.67 \mathrm{~cd}$ & 9.00 no & $24.17 \mathrm{e}-\mathrm{i}$ & $140.44 \mathrm{mn}$ & $12.33 \mathrm{tu}$ & $14.56 \mathrm{r}$ & $7.67 \mathrm{gh}$ \\
\hline Sentu-18 & $120.33 \mathrm{c}$ & $109.67 \mathrm{de}$ & $151.00 \mathrm{ab}$ & $12.33 \mathrm{c}$ & $10.33 \mathrm{k}$ & $24.33 \mathrm{e}-\mathrm{i}$ & $166.85 \mathrm{ij}$ & $24.33 \mathrm{~h}-\mathrm{k}$ & $17.74 \mathrm{~m}$ & $8.17 \mathrm{~d}-\mathrm{g}$ \\
\hline Fullota & $80.67 \mathrm{p}$ & $109.67 \mathrm{de}$ & $144.00 \mathrm{f}$ & $10.67 \mathrm{~d}$ & $5.33 \mathrm{q}$ & $23.50 \mathrm{f}-\mathrm{i}$ & 100.420 & $25.11 \mathrm{~h}-\mathrm{j}$ & $11.24 \mathrm{u}$ & $6.17 \mathrm{i}$ \\
\hline Merygold & $91.67 \mathrm{~lm}$ & $106.33 \mathrm{f}-\mathrm{h}$ & $151.33 \mathrm{a}$ & $14.67 \mathrm{bc}$ & $9.67 \mathrm{~lm}$ & $25.42 \mathrm{~b}-\mathrm{f}$ & $164.00 \mathrm{j}$ & $16.44 \mathrm{q}-\mathrm{s}$ & 16.260 & $8.00 \mathrm{e}-\mathrm{g}$ \\
\hline Lalmatia & $71.33 \mathrm{q}$ & $114.33 \mathrm{bc}$ & $147.00 \mathrm{de}$ & $11.67 \mathrm{~cd}$ & $9.33 \mathrm{mn}$ & $24.83 \mathrm{~d}-\mathrm{h}$ & $136.00 \mathrm{n}$ & $47.00 \mathrm{~d}$ & $15.60 \mathrm{p}$ & $7.83 \mathrm{fg}$ \\
\hline Chapal-2 & $95.50 \mathrm{kl}$ & 105.00 g-i & $137.67 \mathrm{ij}$ & $14.00 \mathrm{bc}$ & $12.50 \mathrm{f}-\mathrm{h}$ & $25.42 \mathrm{~b}-\mathrm{f}$ & $176.00 \mathrm{~h}$ & $26.22 \mathrm{hi}$ & $19.93 \mathrm{kl}$ & $8.83 \mathrm{c}-\mathrm{e}$ \\
\hline Sentu-6 & $105.67 \mathrm{j}$ & 105.00 g-i & $137.00 \mathrm{jk}$ & $15.00 \mathrm{~b}$ & $13.33 \mathrm{e}$ & $26.67 \mathrm{a}-\mathrm{d}$ & $172.78 \mathrm{hi}$ & $45.78 \mathrm{de}$ & $19.60 \mathrm{l}$ & $8.67 \mathrm{c}-\mathrm{f}$ \\
\hline Sentushail & $96.67 \mathrm{k}$ & $110.33 \mathrm{de}$ & $141.33 \mathrm{~g}$ & $16.33 \mathrm{ab}$ & $11.50 \mathrm{ij}$ & $26.17 \mathrm{~b}-\mathrm{e}$ & $175.00 \mathrm{~h}$ & $13.78 \mathrm{st}$ & $19.99 \mathrm{jk}$ & $8.67 \mathrm{c}-\mathrm{f}$ \\
\hline Sentu-17 & $110.45 \mathrm{hi}$ & $105.67 \mathrm{gh}$ & $135.33 \mathrm{k}$ & $15.00 \mathrm{~b}$ & $13.33 \mathrm{e}$ & 24.33f-i & $210.00 \mathrm{~d}$ & $54.78 \mathrm{c}$ & $23 \mathrm{e}$ & $9.17 \mathrm{bc}$ \\
\hline Sentu-16 & $132.33 \mathrm{a}$ & 105.33 g-i & $150.33 \mathrm{ab}$ & $18.00 \mathrm{a}$ & $16.50 \mathrm{a}$ & 23.00 g-i & $245.89 \mathrm{a}$ & $17.45 \mathrm{p}-\mathrm{r}$ & $26.70 \mathrm{c}$ & $10.33 \mathrm{a}$ \\
\hline Ranishail & $134.67 \mathrm{a}$ & $117.67 \mathrm{a}$ & $151.33 \mathrm{a}$ & $17.67 \mathrm{a}$ & $16.33 \mathrm{a}$ & $24.00 \mathrm{f}-\mathrm{i}$ & $250.11 \mathrm{a}$ & $42.89 \mathrm{e}$ & $20.33 \mathrm{ij}$ & $10.17 \mathrm{a}$ \\
\hline Sentu-5 & $95.00 \mathrm{k}-\mathrm{m}$ & $97.67 \mathrm{j}$ & $135.67 \mathrm{k}$ & $11.67 \mathrm{~cd}$ & $11.00 \mathrm{j}$ & $27.50 \mathrm{ab}$ & $155.89 \mathrm{k}$ & $66.67 \mathrm{a}$ & 16.330 & $8.00 \mathrm{e}-\mathrm{g}$ \\
\hline Mean & 105.26 & 109.30 & 145.62 & 14.25 & 11.88 & 24.69 & 173.01 & 28.26 & 19.33 & 8.42 \\
\hline Minimum & 71.33 & 97.67 & 135.33 & 8.67 & 5.33 & 22.33 & 70.03 & 9.11 & 9.38 & 4.91 \\
\hline Maximum & 134.67 & 118.00 & 151.33 & 18.00 & 16.50 & 28.83 & 250.11 & 66.67 & 31.42 & 10.33 \\
\hline$\overline{\mathrm{SE}}$ & 2.27 & 1.43 & 0.91 & 1.32 & 0.26 & 1.15 & 3.85 & 1.64 & 0.19 & 0.46 \\
\hline SD & 18.38 & 4.97 & 5.62 & 2.29 & 2.65 & 1.89 & 40.66 & 14.92 & 4.97 & 1.23 \\
\hline $\begin{array}{l}\text { Level of } \\
\text { significance }\end{array}$ & $* *$ & ** & $* *$ & ** & $* *$ & ** & $* *$ & ** & ** & ** \\
\hline LSD (0.05) & 4.53 & 2.86 & 1.81 & 1.81 & 0.53 & 2.30 & 7.71 & 3.28 & 0.38 & 0.93 \\
\hline CV (\%) & 2.63 & 1.60 & 0.76 & 9.03 & 2.73 & 5.70 & 2.73 & 7.10 & 1.20 & 6.74 \\
\hline
\end{tabular}

Note: $* *$ indicates significant at $1 \%$ level of probability. [Here, $\mathrm{PH}=$ Plant height, $\mathrm{DFF}=$ Days to $50 \%$ flowering, DM= Days to maturity, TTH $=$ Total tillers/hill (no.), ET = Effective tillers/hill (no.), PL= Panicle length (cm), FGP = Filled grains/panicle (no.), UGP = Unfilled grain/panicle (no.), TGW= 1000-grain weight (g) and GYP = Grain yield/plant (g)]

variability for all the studied traits in their experiment $(19,20)$. Significant $(p<0.01)$ variations were seen for individual traits which were also observed by many other researchers for plant height (21-23); for days to $50 \%$ flowering $(24,25)$; for days to maturity $(26)$; for results were almost similar to the earlier findings (22). Germplasm viz. Sentu-17 might be useful in future breeding program to develop short duration variety.

With the advancement of growth stages, the tiller number of the varieties increased. But it was not 
consistent because reduced number of tillers/hill was observed in some of the germplasm at harvest. The reason behind the reduction was the death of some tillers. Number of total tillers/hill ranged from 8.67 (Pairjaat) to 18.00 (Sentu-16) and the mean was 14.25. On the other hand, effective tiller number depends on the number of tillers produced (32) which is the most important parameter for rice. The number of effective tillers/hill was found the highest (16.50) for Sentu-16 and the lowest (5.33) for Fullota in this study as the varieties are genetically different which was primarily influenced by heredity. Panicle length directly controls the yield of a particular variety (33). The longest panicle $(28.83 \mathrm{~cm})$ was recorded in Gaindha and the shortest $(22.33 \mathrm{~cm})$ in Rupashail. These variations in length of panicle might be due to their genetic makeup. The findings were in line with Hoque and Khanam $(29,34)$.

Ranishail possessed the highest number of filled grains/panicle (250.11) which may be due to lower sensitiveness of this genotype to heat stress (e.g. excessive temperature, low sunshine hour) at grain heritability, GA and GA\% of the studied traits. The values of $\sigma_{G}^{2}$ and $\sigma^{2}$ pere the highest for filled grains/panicle and the other traits had the lowest value in this case. Besides, the values of genotypic variance were inferior to phenotypic variance for all the studied quantitative traits, expressing the optimum environmental effect on yield/plant (Table 2). Earlier works also reported the same result in their study (37-39). The highest differences for PCV and GCV were observed for total tillers/hill, panicle length and grain yield/plant; rest of the traits had lower differences between GCV and PCV. The results were consistent with the results of earlier works (37, 40-42). In order to predict the reliability of phenotypic value, heritability was measured. Table 2 presents high broad sense heritability $\left(h^{2} b\right)$ for all the studied traits except number of total tillers/hill and grain yield/plant. Many earlier researchers also reported high heritability for these traits (43-45). High GA in percentage of mean was observed in effective tillers/hill, panicle length, filled grains/panicle, unfilled grains/panicle and 1000-grain weight. Pandey and Anurag also recorded high GA\% in their study for

Table 2. Estimation of genetic parameters for quantitative morphological characters related to yield

\begin{tabular}{|c|c|c|c|c|c|c|c|}
\hline Characters & $\operatorname{PV}\left(\sigma_{p}^{2}\right)$ & $\mathbf{G V}\left(\sigma_{\mathrm{g}}^{2}\right)$ & PCV (\%) & GCV (\%) & $\mathbf{h}^{2} \mathbf{b}(\%)$ & GA & GA (\%) \\
\hline Plant height (cm) & 345.24 & 337.55 & 17.65 & 17.45 & 97.77 & 37.42 & 35.55 \\
\hline Days to 50\% flowering & 24.85 & 21.79 & 4.56 & 4.27 & 87.69 & 9.01 & 8.24 \\
\hline Days to maturity & 32.26 & 31.03 & 3.90 & 3.83 & 96.18 & 11.25 & 7.73 \\
\hline Total tillers/hill (no.) & 6.17 & 4.51 & 17.43 & 14.90 & 73.04 & 3.74 & 26.23 \\
\hline Effective tillers/hill (no.) & 7.20 & 7.09 & 22.59 & 22.42 & 98.54 & 5.45 & 45.85 \\
\hline Panicle length $(\mathrm{cm})$ & 7.53 & 6.64 & 25.19 & 23.67 & 88.24 & 4.99 & 45.79 \\
\hline Filled grains/panicle (no.) & 1689.75 & 1667.48 & 23.76 & 23.60 & 98.68 & 83.56 & 48.30 \\
\hline Unfilled grains/panicle (no.) & 227.61 & 223.58 & 53.39 & 52.91 & 98.23 & 30.53 & 108.03 \\
\hline 1000-grain weight (g) & 25.27 & 25.21 & 26.00 & 25.98 & 99.79 & 10.33 & 53.45 \\
\hline Grain yield/plant(g) & 1.54 & 1.21 & 14.72 & 13.09 & 79.04 & 2.02 & 23.97 \\
\hline
\end{tabular}

[Here, $\sigma_{\mathrm{p}}^{2}=$ Phenotypic variance, $\sigma_{\mathrm{g}}^{2}=$ Genotypic variance, PCV = Phenotypic coefficient of variation, GCV = Genotypic coefficient of variation, $\mathrm{h}^{2} \mathrm{~b}=$ Heritability, $\mathrm{GA}=$ Genetic advance and $\mathrm{GA}(\%)=$ Genetic advance in percentage of mean

filling stage. On the other hand, the lowest value for filled grains/panicle (70.03) was recorded for Gaindha. The results found for this trait was similar to an earlier work (24). In case of unfilled grains/panicle, Sentu-5 contained the maximum (66.67) unfilled grains/panicle and Purabinni had the minimum (9.11). Hoque and Khanam also observed similar type of result for this trait $(29,34)$. The more the thousand grain weight, the more the grain yield. Thousand grain weight ranged from 9.38 to $31.420 \mathrm{~g}$. This trait is used for characterizing rice varieties $(35,36)$. Grain yield/plant is the ultimate goal of rice production. Grain yield/plant ranged from 4.91 to $10.33 \mathrm{~g}$ with a mean 8.42 g. Sentu-16 had the grain/plant in maximum quantity and the lowest amount was found in Gaindha. So, the findings of this study would be useful in finding out the suitable genotype for future research as characterization through different morphological traits is a key step for assessment of genetic potential of rice.

Estimation of genetic variability, heritability and genetic advance of the studied rice germplasm for yield contributing traits

The results of Table 2 express the result for phenotypic and genotypic variances, PCV and GCV, these traits (46). High heritability coupled with high GA (\%) was observed for effective tillers/hill, panicle length, filled grains/panicle, unfilled grains/panicle and 1000-grain weight. Similar trend of high heritability with high GA for different traits in rice was also reported earlier (47). Traits having high heritability $\left(h^{2} b\right)$ accompanied by high GA might be more advantageous in predicting gain than heritability alone. So the findings of this study might be useful in order to find out the expected traits for crop improvement programmes.

\section{Character association between yield and yield contributing traits}

Table 3 indicates the relationship between the phenotypic and genotypic correlation coefficients among different yield and yield contributing traits. In most of the cases, genotypic correlation coefficients were greater than the phenotypic correlation coefficients suggesting that the association was mainly due to genetic reason. The findings were corroborated with the earlier report (40). Grain yield/plant was positively and significantly correlated with plant height, total tillers/hill, effective tillers/hill, filled grains/panicle and 1000-grain weight which indicate the simultaneous improvement of crops. Similar kind 
Table 3. Estimation of phenotypic and genotypic correlation coefficients for quantitative morphological traits related to yield

\begin{tabular}{|c|c|c|c|c|c|c|c|c|c|c|}
\hline Characters & Cor. & DFF & DM & $\begin{array}{l}\text { TTH } \\
\text { (no.) }\end{array}$ & ET (no.) & $\begin{array}{c}\text { PL } \\
\text { (cm) }\end{array}$ & FGP (no.) & $\begin{array}{l}\text { UGP } \\
\text { (no.) }\end{array}$ & TGW (g) & GYP (g) \\
\hline \multirow{2}{*}{$\mathrm{PH}(\mathrm{cm})$} & $r_{p}$ & 0.274 & 0.331 & $0.403^{*}$ & $0.731^{* *}$ & -0.301 & $0.748^{* *}$ & -0.120 & $0.708^{* *}$ & $0.686^{* *}$ \\
\hline & $r_{g}$ & 0.283 & 0.333 & $0.422^{*}$ & $0.739^{* *}$ & -0.340 & $0.752^{* *}$ & -0.119 & $0.712^{* *}$ & $0.711^{* *}$ \\
\hline DFF & $r_{g}$ & & $0.561^{* *}$ & 0.047 & -0.001 & -0.343 & 0.107 & -0.313 & 0.067 & 0.028 \\
\hline \multirow{2}{*}{ DM } & $\mathrm{r}_{\mathrm{p}}$ & & & 0.155 & -0.015 & -0.138 & 0.031 & -0.344 & 0.033 & -0.088 \\
\hline & $r_{g}$ & & & 0.166 & -0.016 & -0.168 & 0.031 & -0.350 & 0.033 & -0.091 \\
\hline TTH (no.) & $r_{g}$ & & & & $0.748^{* *}$ & 0.054 & $0.500^{* *}$ & -0.079 & $0.552^{* *}$ & $0.540^{* *}$ \\
\hline \multirow{2}{*}{ ETH (no.) } & $\mathrm{r}_{\mathrm{p}}$ & & & & & -0.186 & $0.816^{* *}$ & 0.011 & $0.854^{* *}$ & $0.877^{* *}$ \\
\hline & $r_{g}$ & & & & & -0.215 & $0.821^{* *}$ & 0.012 & $0.857^{* *}$ & $0.910^{* *}$ \\
\hline \multirow{2}{*}{ PL (cm) } & $\mathrm{r}_{\mathrm{p}}$ & & & & & & $-0.481^{* *}$ & 0.313 & -0.334 & $-0.365^{*}$ \\
\hline & $r_{g}$ & & & & & & $-0.553^{* *}$ & $0.368 *$ & $-0.384^{*}$ & $-0.442^{*}$ \\
\hline \multirow{2}{*}{ FGP (no.) } & $\mathrm{r}_{\mathrm{p}}$ & & & & & & & -0.097 & $0.795^{* *}$ & $0.886^{* *}$ \\
\hline & $\mathrm{r}_{\mathrm{g}}$ & & & & & & & -0.097 & $0.797^{* *}$ & $0.923^{* *}$ \\
\hline UGP (no.) & $\mathrm{r}_{\mathrm{p}}$ & & & & & & & & -0.118 & -0.114 \\
\hline \multirow{2}{*}{ TGW (g) } & $\mathrm{r}_{\mathrm{p}}$ & & & & & & & & & $0.847^{* *}$ \\
\hline & $\mathrm{r}_{\mathrm{g}}$ & & & & & & & & & $0.881^{* *}$ \\
\hline
\end{tabular}

Note: * and ** indicate significant at $5 \%$ and $1 \%$ level of probability, respectively.

[Cor.= Correlation, $\mathrm{PH}=$ Plant height, DFF= Days to 50\% flowering, DM= Days to maturity, TTH = Total tillers/hill (no.), ET = Effective tillers/hill (no.), PL= Panicle length (cm), FGP = Filled grains/panicle (no.), UGP = Unfilled grains/panicle (no.), TGW= 1000-grain weight (g) and GYP = Grain yield/plant (g)]

of association was also revealed in the works of other researchers $(48,49)$. Plant height exhibited positive and highly significant correlation with total tillers/hill, effective tillers/hill, filled grains/panicle, 1000-grain weight and grain yield/plant. Similar trend of findings was also reported previously $(48,50)$. In case of days to $50 \%$ flowering, the relationship was positively significant with only days to maturity $(51,52)$. Total tillers/hill was positively and significantly correlated with effective tillers/hill, filled grains/panicle, 1000grain weight and grain yield/plant. A similar result was found by other researchers for effective tillers/hill $(24,53)$ and for grain yield/plant $(24,48)$ in previous experiments. Regarding effective tillers/hill, the correlation was highly significant and positive with filled grains/panicle, 1000-grain weight and grain yield/plant. On the other hand, panicle length showed negative but significant association with filled grains/panicle and grain yield/plant. Similar results were recorded for the association of panicle length with other yield contributing traits $(48,54)$. For filled grains/panicle, positively significant correlation was found with 1000-grain weight and grain yield/plant which was also revealed for grain yield $(50,55)$. Thousand grain weight expressed positive and highly significant correlation with grain yield/plant. The result was in line with the results of some earlier experiments $(48,55)$. The positive and significant correlation between the traits suggested that the association was less affected by the environmental factors. So, these traits could be used as criteria for selection for higher yield.

The correlation values are divided into direct and indirect effects through path coefficient analysis for measuring the relative importance of associated causal factors (Table 4 and 5). The values from the table implied that days to $50 \%$ flowering, effective tillers/hill, panicle length, filled grains/panicle and 1000-grain weight exerted positive direct effect on grain yield/plant at both phenotypic and genotypic level. Similar trend of result was reported earlier and found that number of effective tillers/hill and filled grains had positive direct effect on grain yield/plant $(49,56)$. Direct positive effect of previously mentioned traits on grain yield/plant suggested that the selection of these traits would be effective for improving grain yield in rice. Number of effective tillers/hill exerted the highest direct positive effect on grain yield/plant at both phenotypic and genotypic level (57). In case of

Table 4. Phenotypic path coefficient analysis showing direct and indirect effects of the quantitative traits on yield of rice

\begin{tabular}{lcccccccccc}
\hline Characters & PH(cm) & DFF & DM & TTH (no.) & ET (no.) & PL (cm) & FGP(no.) & UGP(no.) & TGW (g) & GYP(g) \\
\hline PH (cm) & $\mathbf{- 0 . 0 9 4}$ & 0.012 & -0.032 & -0.073 & 0.433 & -0.009 & 0.332 & 0.014 & 0.104 & $0.686^{* *}$ \\
\hline DFF & -0.026 & $\mathbf{0 . 0 4 2}$ & -0.052 & -0.009 & -0.002 & -0.008 & 0.046 & 0.035 & 0.010 & 0.036 \\
\hline DM & -0.031 & 0.023 & $\mathbf{- 0 . 0 9 6}$ & -0.028 & -0.009 & -0.004 & 0.014 & 0.039 & 0.005 & -0.088 \\
\hline TTH (no.) & -0.038 & 0.002 & -0.015 & $\mathbf{- 0 . 1 8 1}$ & 0.421 & 0.003 & 0.209 & 0.008 & 0.077 & $0.486^{* *}$ \\
\hline ETH (no.) & -0.069 & -0.0001 & 0.002 & -0.129 & $\mathbf{0 . 5 9 3}$ & -0.006 & 0.362 & -0.001 & 0.125 & $0.877^{* *}$ \\
\hline PL (cm) & 0.028 & -0.012 & 0.013 & -0.017 & -0.110 & $\mathbf{0 . 0 3 0}$ & -0.213 & -0.036 & -0.049 & $-0.365^{*}$ \\
\hline FGP (no.) & -0.071 & 0.004 & -0.003 & -0.085 & 0.484 & -0.0142 & $\mathbf{0 . 4 4 3}$ & 0.011 & 0.117 & $0.886^{* *}$ \\
\hline UGP (no.) & 0.011 & -0.013 & 0.033 & 0.013 & 0.007 & 0.0092 & -0.043 & $\mathbf{- 0 . 1 1 4}$ & -0.017 & -0.114 \\
\hline TGW (g) & -0.067 & 0.003 & -0.003 & -0.095 & 0.506 & -0.0099 & 0.353 & 0.014 & $\mathbf{0 . 1 4 7}$ & $0.847^{* *}$ \\
\hline N & & & &
\end{tabular}

Note: Diagonally bold figures indicate the direct effect. Residual effect: 0.103

[PH= Plant height, DFF= Days to $50 \%$ flowering, DM= Days to maturity, TTH = Total tillers/hill (no.), ET= Effective tillers/hill (no.), PL= Panicle length (cm), FGP = Filled grains/panicle (no.), UGP = Unfilled grains/panicle (no.), TGW= 1000-grain weight (g) and GYP = Grain yield/plant (g)] 
Table 5. Genotypic path coefficient analysis showing direct and indirect effects of the quantitative traits on yield of rice

\begin{tabular}{lcccrrrrrrr}
\hline Characters & PH(cm) & DFF & DM & TTH (no.) & ET (no.) & PL (cm) & FGP(no.) & UGP(no.) & TGW (g) & GYP(g) \\
\hline PH (cm) & $\mathbf{- 0 . 1 6 3}$ & 0.008 & -0.017 & -0.104 & 0.544 & -0.010 & 0.353 & 0.015 & 0.085 & $0.711^{* *}$ \\
\hline DFF & -0.046 & $\mathbf{0 . 0 2 9}$ & -0.029 & -0.012 & -0.001 & -0.010 & 0.052 & 0.039 & 0.008 & 0.028 \\
\hline DM & -0.054 & 0.016 & $\mathbf{- 0 . 0 5 2}$ & -0.042 & -0.015 & -0.005 & 0.014 & 0.044 & 0.004 & -0.091 \\
\hline TTH (no.) & -0.069 & 0.002 & -0.009 & $-\mathbf{0 . 2 4 8}$ & 0.551 & 0.002 & 0.235 & 0.010 & 0.066 & $0.540^{* *}$ \\
\hline ETH (no.) & -0.121 & 0.000 & 0.001 & -0.186 & $\mathbf{0 . 7 3 5}$ & -0.007 & 0.386 & -0.001 & 0.103 & $0.910^{* *}$ \\
\hline PL (cm) & 0.056 & -0.010 & 0.009 & -0.012 & -0.162 & $\mathbf{0 . 0 3 1}$ & -0.259 & -0.047 & -0.046 & $-0.442^{*}$ \\
\hline FGP (no.) & -0.123 & 0.003 & -0.002 & -0.124 & 0.602 & -0.017 & $\mathbf{0 . 4 7 1}$ & 0.013 & 0.096 & $0.923^{* *}$ \\
\hline UGP (no.) & 0.020 & -0.009 & 0.018 & 0.020 & 0.007 & 0.011 & -0.047 & $-\mathbf{0 . 1 2 6}$ & -0.014 & -0.119 \\
\hline TGW (g) & -0.116 & 0.002 & -0.002 & -0.136 & 0.632 & -0.012 & 0.377 & 0.015 & $\mathbf{0 . 1 2 0}$ & $0.881^{* *}$ \\
\hline Not Dia
\end{tabular}

Note: Diagonally bold figures indicate the direct effect. Residual effect: 0.036

PH= Plant height, DFF= Days to $50 \%$ flowering, DM= Days to maturity, TTH = Total tillers/hill (no.), ET= Effective tillers/hill (no.), PL= Panicle length (cm), FGP= Filled grains/panicle (no.), UGP= Unfilled grains/panicle (no.), TGW= 1000-grain weight (g) and GYP= Grain yield/plant (g)

plant height, days to maturity, total tillers/hill and unfilled grains panicle, the effect was direct and negative at both levels which suggested that the direct selection of these traits would not be helpful. The residual effect decides how the best causal factors explain the variability of resultant factor (grain yield/plant). The value for residual effect of phenotypic path coefficient was 0.103, which suggested that the nine characters contributed $89.7 \%$ of variability in grain yield/plant in phenotypic path analysis. The value for residual effect of genotypic path coefficient was 0.036 indicated that the nine characters contributed $96.4 \%$ of variability in grain yield/plant studied in genotypic path analysis. This is due to non-significant correlation of some traits with yield.

\section{Nature and magnitude of genetic diversity for the yield and yield contributing traits}

Different characters contributed differently to the total variation as indicated by their eigen vectors as well as their loading on the different principal axes were known from the results of the PCA (Table 6). The first three components accounted for $79.57 \%$ of the total variation with eigen value of $>1.0$ which was matched with the information provided $(58,59)$. The first component accounted for $48.46 \%$ of the total variation where grain yield/plant had the highest positive value followed by filled grains/panicle, effective tillers/hill, 1000-grain weight, plant height and total tillers/hill whereas the second component accounted for $19.94 \%$ of the total variation explained mostly by days to $50 \%$ flowering, days to maturity and unfilled grains/panicle. The findings were similar with the earlier studies $(24,59,60)$. For PC3, days to maturity, total tillers/hill and panicle length contributed $11.18 \%$ of total variation with panicle length (0.63) given the highest contribution. The result was in consent with the exploratory results of some other researchers (61-63). So, the results expressed that extensive genetic variation was existed in the germplasms of this study. Resulting germplasm of this study will be more effective in finding out the parents for the improvement of yield in rice.

The germplasm were grouped into 5 clusters based on $\mathrm{D}^{2}$ valus (Table 7 and Fig. 1 ) where cluster III and IV had 8 germplasm where each of them covering
Table 6. Principal components (PCs) for quantitative morphological traits of the studied rice genotypes under field condition

\begin{tabular}{lccc}
\hline Characters & PC1 & PC2 & PC3 \\
\hline Plant height (cm) & 0.38 & 0.11 & 0.12 \\
\hline Days to 50\% flowering & 0.09 & 0.56 & 0.13 \\
\hline Days to maturity & 0.07 & 0.55 & 0.43 \\
\hline Total tillers/hill (no.) & 0.29 & -0.11 & 0.53 \\
\hline Effective tillers/hill (no.) & 0.42 & -0.20 & 0.15 \\
\hline Panicle length (cm) & -0.21 & -0.31 & 0.63 \\
\hline Filled grains/panicle (no.) & 0.42 & -0.05 & -0.18 \\
\hline Unfilled grains/panicle (no.) & -0.09 & -0.45 & 0.15 \\
\hline 1000-grain weight (g) & 0.41 & -0.09 & -0.04 \\
\hline Grain yield/plant(g) & 0.43 & -0.14 & -0.16 \\
\hline Eigen value & 4.85 & 1.99 & 1.12 \\
\hline \%Variance explained & 48.46 & 19.94 & 11.18 \\
\hline Cumulative variance (\%) & 48.46 & 68.39 & 79.57 \\
\hline
\end{tabular}

$25.81 \%$ of the total germplasm which were considered as the largest clusters whereas cluster $\mathrm{V}$ was the smallest cluster covering $12.90 \%$ of the total germplasm indicating the presence of genetic diversity. Similar clustering and high degree of genetic diversity were also reported by others in rice $(64,65,66)$. The rice germplasm accumulated in the same cluster indicate that they are not sharply diversified. Cluster I and II covered about 16.13 and $19.35 \%$ of the total studied germplasm, respectively. The results also revealed that no duplication was present for the studied traits.

In most of the cases, the intra-cluster distance was smaller than the inter-cluster distance which indicates that the diversity among the germplasm of this group was broad (Table 8 and Fig. 2). The result was similar to earlier reports $(30,67)$. Maximum intracluster diversity was observed in cluster II while minimum in cluster III. The results indicated that the germplasm belonged in cluster II had more heterogeneity among themselves and germplasm in cluster III were comparatively more closely related. As for the inter-cluster distance, maximum inter-cluster distance was shown from cluster II and cluster V suggesting that hybridization among the studied germplasm having high yield potential taken from these highly divergent clusters might produce heterotic combinations and wider variability in segregating generations. Minimum inter-cluster 
Table 7. Number, percent and name of the genotype in different clusters for yield contributing traits

\begin{tabular}{cccl}
\hline $\begin{array}{c}\text { Cluster } \\
\text { (no.) }\end{array}$ & $\begin{array}{c}\text { Number of } \\
\text { varieties }\end{array}$ & Percent (\%) & Name of the genotype \\
\hline I & 5 & 16.13 & Gaindha, Purabinni, Lalchinishail, Mery gold and Sentu-5 \\
\hline II & 6 & 19.35 & Fulkainja, Rupashail, Ledabinni, Bishalibinni, Sentu-16 and Ranishail \\
\hline III & 8 & 25.81 & $\begin{array}{l}\text { Biroi, Chapal, Dudhbinni, Motamorang, Markabinni, Goatibinni, Shongbinni and } \\
\text { Sentu-18 }\end{array}$ \\
\hline IV & 8 & 25.81 & $\begin{array}{l}\text { Sentu-15, Sentu-19, Champamasuri, Sentu gold, Chapal-2, Sentu-6, Sentushail and } \\
\text { Sentu-17 }\end{array}$ \\
\hline V & 4 & Chotosornolota, Pairjaat, Fullota and Lalmatia \\
\hline
\end{tabular}

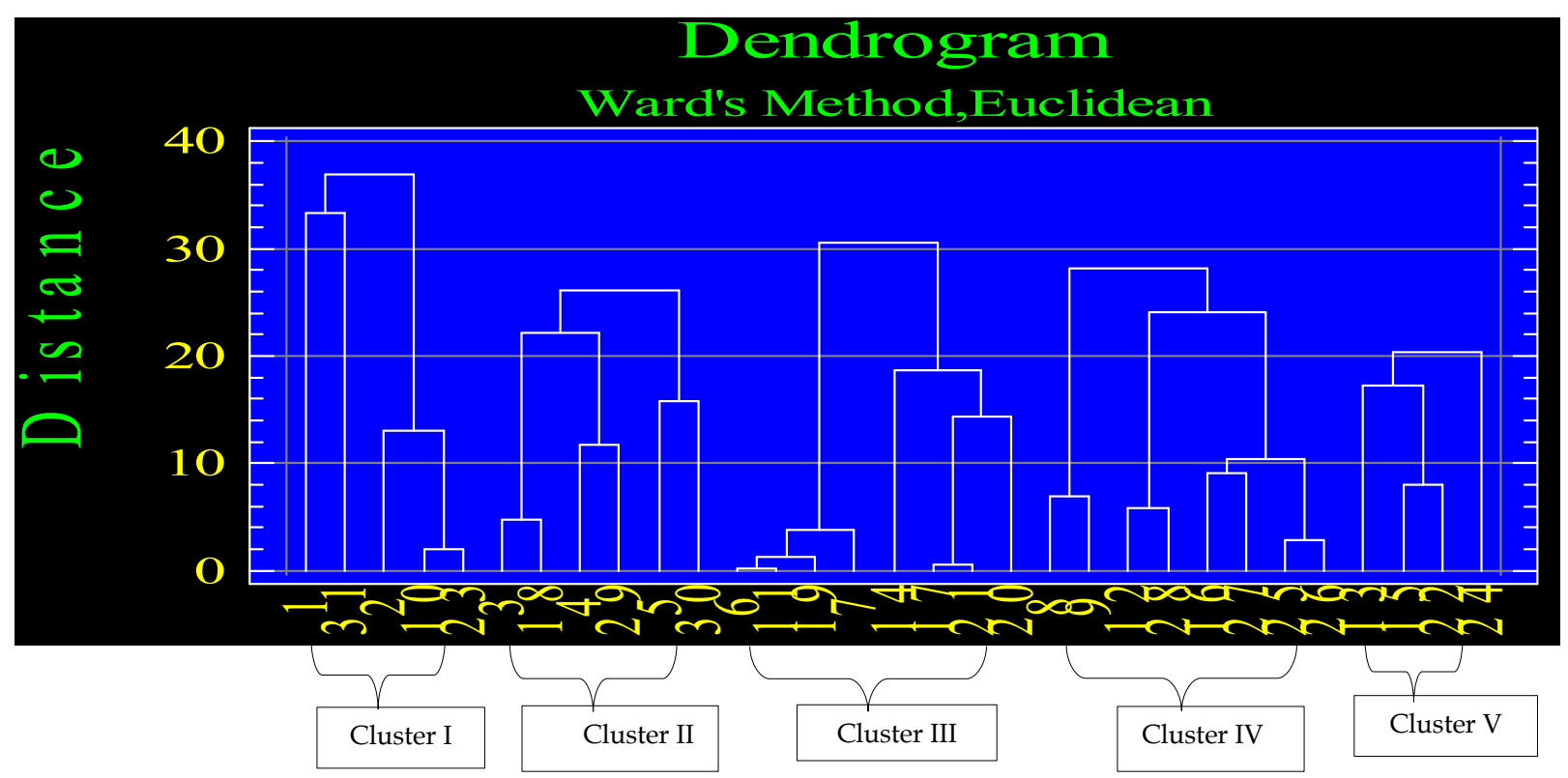

Fig. 1. Dendrogram based on summarized data on differentiation among the rice germplasm according to Ward's method [1.Gaindha, 2.Purabinni, 3.Fulkainja, 4.Rupashail, 5. Leda binni, 6.Biroi, 7.Chapal, 8.Sentu-15, 9.Sentu-19, 10.Lalchinishail, 11.Dudhbinni, 12.Champamashuri, 13.Chotosornolota, 14.Motamorang, 15.Pairjaat, 16.Sentu gold, 17.Markabinni, 18.Bishalibinni, 19.Goatibinni, 20.Shongbinni, 21.Sentu-18, 22.Fullota, 23.Mery gold, 24.Lalmatia, 25.Chapal-2, 26.Sentu-6, 27.Sentushail, 28.Sentu-17, 29.Sentu-16, 30.Ranishail and 31.Sentu-5].

distance was observed between cluster I and cluster $\mathrm{V}$ expressing the narrow diversity between these clusters. Although, the germplasms of these two clusters might not be used for crossing with each other in hybridization programme, it might be used in breeding programme for biparental crosses between the most diverse and the closest groups to break the awful linkage between yield and yield contributing traits.

Table 9 presented the mean performance of different clusters for different quantitative traits. low abundance for these characters was found in cluster $\mathrm{V}$ showing maximum contribution of these traits towards the divergence between cluster II and V. There are studies on mean performance of different clusters on rice germplasm using $\mathrm{D}^{2}$ statistics $(58,68)$. Cluster II included maximum days to $50 \%$ flowering, number of filled grains/panicle and grain yield/plant whereas cluster I had the minimum days to $50 \%$ flowering number of filled grains/panicle and grain yield/plant indicating divergence between cluster I and cluster II. Cluster

Table 8. Average intra and inter-cluster distance among the rice germplasm for yield and yield contributing traits

\begin{tabular}{|c|c|c|c|c|c|}
\hline & $\mathbf{I}$ & II & III & IV & $\mathbf{V}$ \\
\hline $\mathbf{I}$ & $\begin{array}{c}1348.26 \\
(36.72)\end{array}$ & $\begin{array}{c}4978.99 \\
(70.56) \\
\end{array}$ & $\begin{array}{c}1569.11 \\
(39.61) \\
\end{array}$ & $\begin{array}{c}2469.90 \\
(49.70) \\
\end{array}$ & $\begin{array}{l}892.99 \\
(29.88) \\
\end{array}$ \\
\hline II & & $\begin{array}{l}1399.34 \\
(37.41)\end{array}$ & $\begin{array}{c}2258.72 \\
(47.53) \\
\end{array}$ & $\begin{array}{c}1544.09 \\
(39.29) \\
\end{array}$ & $\begin{array}{c}5310.76 \\
(72.87) \\
\end{array}$ \\
\hline III & & & $\begin{array}{l}537.11 \\
(23.18)\end{array}$ & $\begin{array}{c}1050.80 \\
(32.42) \\
\end{array}$ & $\begin{array}{c}1462.52 \\
(38.24)\end{array}$ \\
\hline IV & & & & \begin{tabular}{|l|}
628.19 \\
$(25.06)$ \\
\end{tabular} & $\begin{array}{c}2559.76 \\
(50.59)\end{array}$ \\
\hline $\mathbf{V}$ & & & & & $\begin{array}{l}613.64 \\
(24.77) \\
\end{array}$ \\
\hline
\end{tabular}

Note: Bold value in the table indicates intra-cluster distance

The result revealed that cluster II was characterized by high abundance of plant height, total tillers/hill, effective tillers/hill and 1000-grain weight whereas
II included germplasm with maximum days to maturity whereas cluster IV included germplasm with minimum days to maturity indicating 


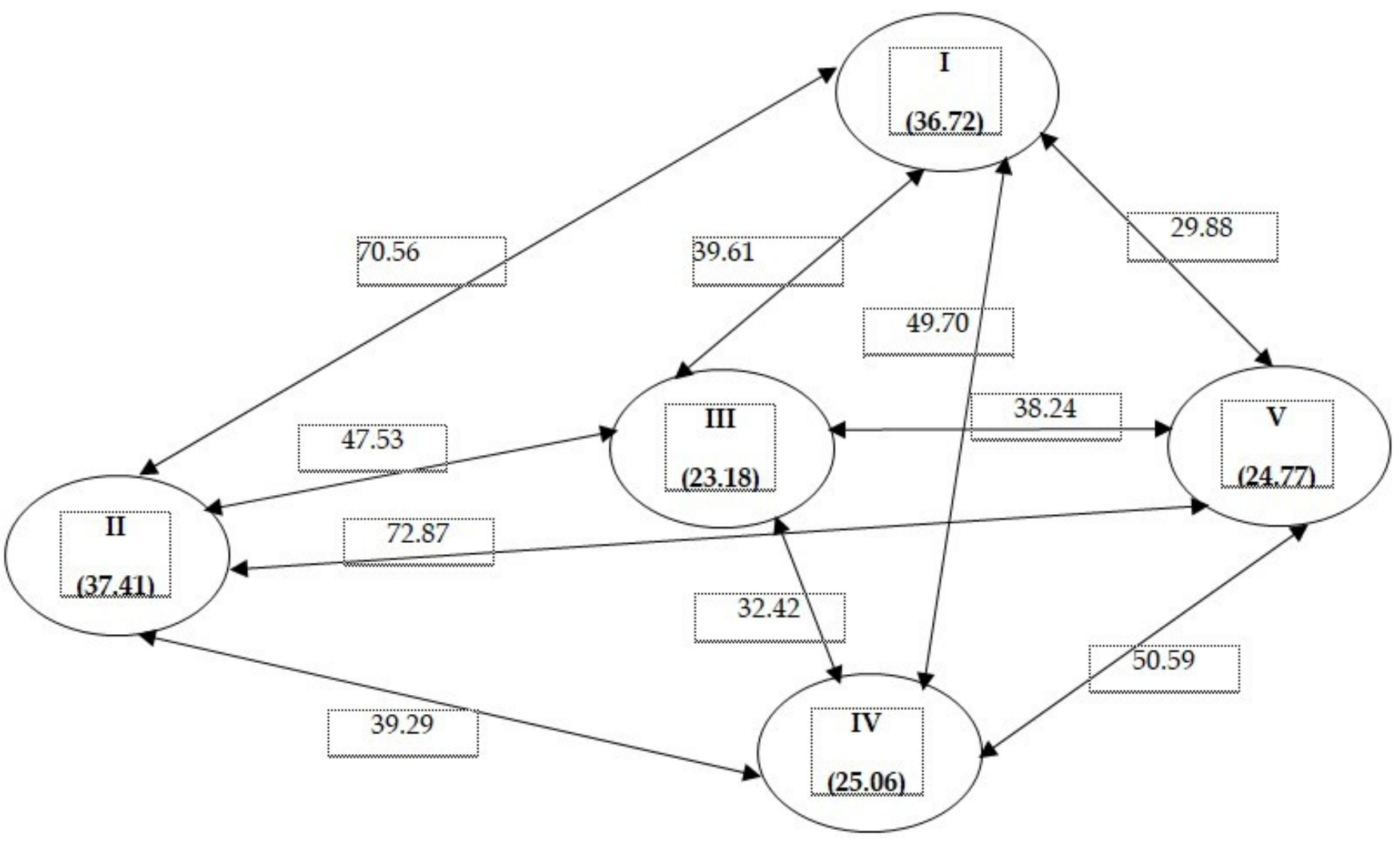

Fig. 2. Diagram showing intra- and inter-cluster distances of the studied rice genotypes.

Table 9. Cluster means for ten characters related to yield of the rice germplasm

\begin{tabular}{|c|c|c|c|c|c|}
\hline Characters & Cluster I & Cluster II & Cluster III & Cluster IV & Cluster V \\
\hline Plant height $(\mathrm{cm})$ & 87.25 & 128.78 & 115.51 & 101.40 & 79.72 \\
\hline Days to $50 \%$ flowering & 105.27 & 113.06 & 111.79 & 105.92 & 110.50 \\
\hline Days to maturity & 147.40 & 150.44 & 148.67 & 139.00 & 143.33 \\
\hline Total tillers/hill (no.) & 14.60 & 16.28 & 13.42 & 15.29 & 10.34 \\
\hline Effective tillers/hill (no.) & 9.90 & 15.00 & 11.46 & 13.17 & 7.92 \\
\hline $\begin{array}{l}\text { Panicle length }(\mathrm{cm}) \\
\end{array}$ & 26.82 & 23.36 & 24.37 & 25.05 & 23.94 \\
\hline Filled grains/panicle (no.) & 127.62 & 224.57 & 173.93 & 183.05 & 130.47 \\
\hline Unfilled grains/panicle (no.) & 35.36 & 28.14 & 19.92 & 31.42 & 29.95 \\
\hline 1000-grain weight (g) & 14.36 & 25.45 & 18.82 & 21.33 & 13.41 \\
\hline Grain yield/plant(g) & 7.09 & 9.63 & 8.38 & 8.98 & 7.26 \\
\hline
\end{tabular}

divergence between cluster II and cluster IV. Germplasm with the longest panicle were included in cluster I whereas cluster II had the shortest ones indicating divergence between cluster I and cluster II. Maximum number of unfilled grains/panicle was contained by cluster I while cluster III had minimum number of unfilled grains/panicle indicating divergence between cluster I and cluster III. The mean values of cluster groups revealed that cluster II was highly divergent among the all cluster groups. The traits included in this cluster viz., plant height, days to $50 \%$ flowering, days to maturity, total tillers/hill, number of effective tillers/hill, filled grains/panicle, 1000-grain weight and grain yield/plant contributed maximum towards the total divergence. The genetically diverse genotypes become more important for developing variety resistant to diseases and adverse climatic conditions as the modern variety with narrow genetic bases are vulnerable to these (2). So, traits having broad genetic bases found from this study can be used for developing a resistant variety as well as reducing yield losses.

\section{Characterization based on qualitative characters using DUS test}

Distinctness, uniformity and stability test was done to characterize the qualitative morphological traits of the studied rice germplasm (Table 10). Out of 31 qualitative traits, 5 showed homogeneity (blade pubescence, basal leaf sheath color, ligule shape, auricle color and decorticated grain: scent) and the rest 26 showed heterogeneity. All the germplasm possessed glabrous typed pubescence, green colored leaf sheath, 2-cleft shaped ligule, pale green colored auricle and non-scented decorticated grains.

\section{Pigmentation}

Regarding the leaf blade color, 9\% germplasms had pale green, $66 \%$ germplasms had green and $25 \%$ had dark green leaf blade. There are reports on the highest frequency for green leaf blade (69). In case of leaf sheath and culm anthocyanin coloration, only Dudhbinni possessed it. Studies are also on greater variation for leaf sheath and culm anthocyanin coloration (70, 71). Among the germplasms evaluated, 
Table 10. Characterization of rice germplasm based on qualitative characters during Aman season

\begin{tabular}{|c|c|c|c|c|c|}
\hline Sl. No. & Characters & $\begin{array}{l}\text { State of } \\
\text { characters }\end{array}$ & $\begin{array}{l}\text { Germplasm } \\
\text { (no.) }\end{array}$ & Germplasm & $\begin{array}{l}\text { Frequency } \\
\text { (\%) }\end{array}$ \\
\hline 1 & Blade pubescence & Glabrous & 31 & $\begin{array}{l}\text { 1,2,3,4,5,6,7,8,9,10,11,12,13,14,15,16,17,18,19,20,21,22,23,24,25,26,27,28, } \\
29,30,31\end{array}$ & 100 \\
\hline \multirow{3}{*}{2} & \multirow{3}{*}{ Blade color } & Pale green & 1 & 3 & 9.68 \\
\hline & & Green & 21 & $1,2,4,6,7,10,11,12,15,16,17,20,21,22,24,25,26,27,29,30,31$ & 67.74 \\
\hline & & Dark green & 8 & $5,8,9,13,14,18,19,23$ & 25.81 \\
\hline \multirow[t]{2}{*}{3} & \multirow{2}{*}{$\begin{array}{l}\text { Leaf sheath: } \\
\text { anthocyanin color }\end{array}$} & Absent & 30 & $\begin{array}{l}\text { 1,2,3,4,5,6,7,8,9,10,12,13,14,15,16,17,18,19,20,21,22,23,24,25,26,27,28,29, } \\
30,31\end{array}$ & 96.77 \\
\hline & & Present & 1 & 11 & 3.23 \\
\hline 4 & $\begin{array}{l}\text { Basal leaf sheath } \\
\text { color }\end{array}$ & Green & 31 & $1-31$ & 100 \\
\hline \multirow{2}{*}{5} & \multirow{2}{*}{ Leaf angle } & Erect & 12 & $11,13,14,15,24,25,26,27,28,29,30,31$ & 38.71 \\
\hline & & Horizontal & 19 & $1,2,3,4,5,6,7,8,9,10,12,16,17,18,19,20,21,22,23$ & 61.29 \\
\hline \multirow{2}{*}{6} & \multirow{2}{*}{ Flag leaf angle } & Erect & 16 & $3,4,8,9,13,14,18,19,24,25,26,27,28,29,30,31$ & 51.61 \\
\hline & & Semi-erect & 15 & $1,2,5,6,7,10,11,12,15,16,17,20,21,22,23$ & 48.39 \\
\hline \multirow{3}{*}{7} & \multirow{3}{*}{ Ligule color } & White & 25 & $1,3,5,6,7,8,10,12,13,15,16,17,18,19,21,22,23,24,25,26,27,28,29,30,31$ & 80.65 \\
\hline & & Purple lines & 5 & $2,4,9,14,20$ & 16.13 \\
\hline & & Purple & 1 & 11 & 3.23 \\
\hline 8 & Ligule shape & 2-cleft & 31 & $\begin{array}{l}\text { 1,2,3,4,5,6,7,8,9,10,11,12,13,14,15,16,17,18,19,20,21,22,23,24,25,26,27,28, } \\
29,30,31\end{array}$ & 100 \\
\hline \multirow{3}{*}{9} & \multirow{3}{*}{ Collar color } & Pale green & 29 & $\begin{array}{l}\text { 1,2,3,4,5,6,7,9,10,12,13,14,15,16,17,18,19,20,21,22,23,24,25,26,27,28,29,30, } \\
31\end{array}$ & 93.55 \\
\hline & & Green & 1 & 8 & 3.23 \\
\hline & & Purple & 1 & 11 & 3.23 \\
\hline 10 & Auricle color & Pale green & 31 & $\begin{array}{l}\text { 1,2,3,4,5,6,7,8,9,10,11,12,13,14,15,16,17,18,19,20,21,22,23,24,25,26,27,28, } \\
29,30,31\end{array}$ & 100 \\
\hline \multirow[t]{2}{*}{11} & \multirow{2}{*}{$\begin{array}{l}\text { Culm anthocyanin } \\
\text { color }\end{array}$} & Absent & 30 & $\begin{array}{l}\text { 1,2,3,4,5,6,7,8,9,10,12,13,14,15,16,17,18,19,20,21,22,23,24,25,26,27,28,29, } \\
30,31\end{array}$ & 96.77 \\
\hline & & Present & 1 & 11 & 3.23 \\
\hline \multirow{4}{*}{12} & \multirow{4}{*}{ Culm angle } & Erect & 17 & $4,5,8,9,12,13,16,19,22,24,25,26,27,28,29,30,31$ & 54.84 \\
\hline & & Intermediate & 9 & $1,3,6,7,10,11,14,17,18,23$ & 29.03 \\
\hline & & Open & 3 & $2,20,21$ & 9.68 \\
\hline & & Spreading & 1 & 15 & 3.23 \\
\hline \multirow{2}{*}{13} & \multirow{2}{*}{ Internode color } & Green & 19 & $2,3,4,5,8,9,11,12,14,15,16,18,20,22,23,24,27,29,30$ & 61.29 \\
\hline & & Light gold & 12 & $1,6,7,10,13,17,19,21,3125,26,28$ & 38.71 \\
\hline \multirow{5}{*}{14} & \multirow{5}{*}{$\begin{array}{l}\text { Culm strength } \\
\text { (lodging resistance) }\end{array}$} & Strong & 1 & 18 & 3.23 \\
\hline & & $\begin{array}{l}\text { Moderately } \\
\text { strong }\end{array}$ & 10 & $5,6,8,9,16,20,25,26,29,30$ & 32.26 \\
\hline & & Intermediate & 8 & $3,4,14,22,23,24,27,28$ & 25.81 \\
\hline & & Weak & 11 & $1,2,7,10,11,12,13,15,17,21,31$ & 35.48 \\
\hline & & Very weak & 1 & 19 & 3.23 \\
\hline \multirow{2}{*}{15} & Panicle tyne & Intermediate & 27 & $1,3,4,5,7,8,9,10,11,12,13,14,15,16,17,18,20,21,22,23,24,25,26,28,29,30,31$ & 87.10 \\
\hline & Panicle type & Open & 4 & $2,6,19,27$ & 12.90 \\
\hline & Secondary & Absent & 7 & $2,5,6,7,8,11,20$ & 22.58 \\
\hline 16 & branching & Light & 24 & $1,3,4,9,10,12,13,14,15,16,17,18,19,21,22,23,24,25,26,27,28,29,30,31$ & 77.42 \\
\hline & & Partly exerted & 8 & $5,12,13,16,22,25,26,28$ & 25.81 \\
\hline & & Just exerted & 10 & $8,9,10,11,14,17,18,20,21,31$ & 32.26 \\
\hline 17 & Panicle exertion & $\begin{array}{l}\text { Moderately } \\
\text { well exerted }\end{array}$ & 11 & $1,2,3,4,6,7,15,23,24,29,30$ & 35.48 \\
\hline & & Well exerted & 2 & 19,27 & 6.45 \\
\hline 18 & Axic & Straight & 10 & $4,5,8,16,17,18,19,20,29,30$ & 32.26 \\
\hline 18 & Axis & Droopy & 21 & $1,2,3,6,7,9,10,11,12,13,14,15,21,22,23,24,25,26,27,28,31$ & 67.74 \\
\hline & & Very low & 20 & $2,4,5,14,15,16,17,18,19,21,22,23,24,25,26,27,28,29,30,31$ & 64.52 \\
\hline 19 & Shattering & Low & 8 & $1,3,6,9,11,12,13,20$ & 25.81 \\
\hline & & Moderate & 3 & $7,8,10$ & 9.68 \\
\hline & & Difficult & 1 & 19 & 3.23 \\
\hline & & $\begin{array}{l}\text { Moderately } \\
\text { difficult }\end{array}$ & 4 & $5,16,17,31$ & 12.90 \\
\hline 20 & Threshability & Intermediate & 18 & $1,2,3,4,6,9,11,12,13,14,15,21,22,23,26,28,29,30$ & 58.07 \\
\hline & & Loose & 4 & $7,8,10,26$ & 12.90 \\
\hline & & Easy & 4 & $18,20,24,27$ & 12.90 \\
\hline
\end{tabular}




\begin{tabular}{|c|c|c|c|c|c|}
\hline \multirow{5}{*}{21} & \multirow{5}{*}{ Awn: distribution } & None & 25 & $1,2,4,6,7,8,9,10,11,12,13,14,15,16,17,21,22,23,24,25,26,27,28,29,31$ & 80.65 \\
\hline & & Tip only & 4 & $3,5,20,30$ & 12.90 \\
\hline & & $\begin{array}{l}\text { Upper quarter } \\
\text { only }\end{array}$ & 1 & 18 & 3.23 \\
\hline & & $\begin{array}{l}\text { Upper three- } \\
\text { quarters only }\end{array}$ & 1 & 19 & 3.23 \\
\hline & & Whole length & & & 0 \\
\hline \multirow{3}{*}{22} & \multirow{3}{*}{ Awn color } & Straw & 4 & $3,5,18,30$ & 12.90 \\
\hline & & Gold & 0 & & 0 \\
\hline & & Brown (tawny) & 2 & 19,20 & 6.45 \\
\hline \multirow{5}{*}{23} & \multirow{5}{*}{ Apiculus color } & Straw & 11 & $6,8,14,15,16,20,24,25,26,27,28$ & 35.48 \\
\hline & & Brown & 14 & $1,3,4,7,9,10,12,13,21,22,23,29,30,31$ & 45.16 \\
\hline & & Red apex & 2 & 18,19 & 6.45 \\
\hline & & Purple & 1 & 5 & 3.23 \\
\hline & & Black & 3 & $2,11,17$ & 9.68 \\
\hline \multirow{5}{*}{24} & \multirow{5}{*}{ Stigma color } & White & 2 & 6,11 & 6.45 \\
\hline & & Light green & 2 & 2,7 & 6.45 \\
\hline & & Yellow & 22 & $1,3,4,8,9,12,13,14,16,17,19,21,22,23,24,25,26,27,28,29,30,31$ & 70.97 \\
\hline & & Light purple & 2 & 5,10 & 6.45 \\
\hline & & Purple & 3 & $15,18,20$ & 9.68 \\
\hline \multirow{9}{*}{25} & \multirow{9}{*}{$\begin{array}{l}\text { Lemma and palea } \\
\text { color }\end{array}$} & Straw & 6 & $12,25,26,27,28,30$ & 19.36 \\
\hline & & $\begin{array}{l}\text { Gold and } \\
\text { gold furrows } \\
\text { on straw } \\
\text { background }\end{array}$ & 5 & $15,16,20,23,24$ & 16.13 \\
\hline & & $\begin{array}{l}\text { Brown spots } \\
\text { on straw }\end{array}$ & 2 & 1,14, & 6.45 \\
\hline & & $\begin{array}{l}\text { Brown } \\
\text { furrows on } \\
\text { straw }\end{array}$ & 7 & $3,4,7,17,19,22,29$ & 22.58 \\
\hline & & Brown & 4 & $6,8,13,21$ & 12.90 \\
\hline & & $\begin{array}{l}\text { Reddish to } \\
\text { light purple }\end{array}$ & 2 & 9,31 & 6.45 \\
\hline & & Purple & 3 & $5,10,18$ & 9.68 \\
\hline & & Black & 2 & 2,11 & 6.45 \\
\hline & & White & 0 & & 0 \\
\hline \multirow{3}{*}{26} & \multirow{3}{*}{$\begin{array}{l}\text { Lemma and palea } \\
\text { pubescence }\end{array}$} & Glabrous & 22 & $1,2,3,4,6,7,8,10,12,15,16,20,22,23,24,25,26,27,28,29,30,31$ & 70.97 \\
\hline & & $\begin{array}{l}\text { Hairs on } \\
\text { upper } \\
\text { portion }\end{array}$ & 3 & $17,19,21$ & 9.68 \\
\hline & & Short hairs & 6 & $5,9,11,13,14,18$ & 19.36 \\
\hline \multirow{4}{*}{27} & \multirow{4}{*}{$\begin{array}{l}\text { Sterile lemma } \\
\text { color }\end{array}$} & Straw & 14 & $1,2,3,4,6,13,16,22,23,24,25,26,29,30$ & 45.16 \\
\hline & & Gold & 10 & $8,10,12,14,15,18,20,27,28,31$ & 32.26 \\
\hline & & Red & 6 & 7,9,11,17,19,21, & 19.35 \\
\hline & & Purple & 1 & 5 & 3.23 \\
\hline \multirow{6}{*}{28} & \multirow{6}{*}{ Seed coat color } & White & 20 & $2,3,4,5,7,8,9,12,13,14,15,16,17,18,21,22,23,29,30,31$ & 64.52 \\
\hline & & Light brown & 5 & $11,19,26,27,28$ & 16.13 \\
\hline & & $\begin{array}{l}\text { Speckled } \\
\text { brown }\end{array}$ & 1 & 25 & 3.23 \\
\hline & & Brown & 1 & 24 & 3.23 \\
\hline & & $\begin{array}{l}\text { Variable } \\
\text { purple }\end{array}$ & 3 & $6,10,20$ & 9.68 \\
\hline & & Purple & 1 & 1 & 3.23 \\
\hline \multirow{3}{*}{29} & \multirow{3}{*}{ Endosperm type } & $\begin{array}{l}\text { Non-glutinous } \\
\text { (no waxy) }\end{array}$ & 2 & 10,19 & 6.45 \\
\hline & & $\begin{array}{l}\text { Glutinous } \\
\text { (waxy) }\end{array}$ & 23 & $2,3,4,5,6,8,9,12,13,14,15,16,17,18,21,22,23,25,26,27,29,30,31$ & 74.19 \\
\hline & & Intermediate & 6 & $1,7,11,20,24,28$ & 19.36 \\
\hline 30 & $\begin{array}{l}\text { Decorticated grain: } \\
\text { scent }\end{array}$ & Non-scented & 31 & & 100 \\
\hline \multirow{5}{*}{31} & \multirow{5}{*}{ Leaf senescence } & Very early & 11 & $4,6,10,13,14,17,19,21,25,26,31$ & 35.48 \\
\hline & & Early & 2 & 7,12 & 6.45 \\
\hline & & Intermediate & 5 & $1,11,15,16,31$ & 16.13 \\
\hline & & Late and slow & 8 & $3,8,9,18,20,22,24,30$ & 25.81 \\
\hline & & Very late & 5 & $2,5,23,27,29$ & 16.13 \\
\hline
\end{tabular}

$61 \%$ had green pigmented internodes and 39\% had light gold internodes. A large variation was found for ligule color: $81 \%$ germplasms showed white ligule,
$16 \%$ germplasms showed purple line ligule and $3 \%$ germplasms named Dudhbinni showed purple ligule among the studied germplasms. For collar color, pale 
green collar was present in 94\% germplasms, green collar was present in 3\% germplasms and rest of the germplasms had purple collar. There are similar results found from this study for ligule and collar color in rice (69). Studied germplasm having awn showed two colored awn: straw and brown color for $67 \%$ and $33 \%$ germplasm accessions respectively. Significant differences were found for apiculus color: brown apiculus was recorded in 45\%, straw apiculus in $35 \%$, black apiculus in $10 \%$, red apiculus in $6 \%$ and purple apiculus in $3 \%$ of the studied germplasm accessions. Records are on the highest frequency for awn and straw color $(58,72)$. Most of the germplasm had yellow colored stigma (71\%), which is followed by purple (10\%), light green (6\%), white (6\%) and light purple $(6 \%)$ stigma. It was also found distinctive variation for stigma color in their study (69). Out of the studied germplasm, 23\% showed brown furrows on straw background for lemma and palea color which is followed by gold and gold furrows on straw background (16\%), straw (19\%), brown (13\%), purple (10\%), brown spots on straw $(6 \%)$, reddish to light purple (6\%) and black (6\%). So, there exist wide variations in the studied germplasm for lemma and palea color which was also found by other researchers in their studies $(73,74)$. In case of sterile lemma color, $45 \%$ germplasm had straw sterile lemma color, $32 \%$ had gold color, $19 \%$ had red color and 3\% had purple color which was matched with the earlier report (62) but dissimilar to the results reported (72). Seed coat was white in $65 \%$ germplasm. However, seed coat of rest of the germplasm was light brown, variable purple, speckled brown, brown and purple in color. Traits having different pigmentation are very functional and helpful in sorting out of off-types and keeping the seed genetically pure.

\section{Angle of leaf, flag leaf and culm and culm strength}

Majority of the germplasm possessed horizontal type leaf angle (61\%) whereas erect type of angle of leaves were found for $39 \%$ germplasm. On the other hand, flag leaf angle was found erect in 52\% germplasm and semi-erect in $48 \%$. Similar angle of flag leaf was also found by others (72). Erect type of leaf and flag leaf angle helps to accumulate more sunlight and contributes more in photosynthesis as well as producing more photosynthate which results in higher grain yield. Culm angle was found erect for $57 \%$ germplasm, intermediate for $30 \%$ germplasm, open for $10 \%$ germplasm and spreading for one germplasm. Wide variability for culm angle was also reported in rice (75). For 3\% accession, culm strength was found strong, moderately strong for $32 \%$, intermediate for $26 \%$, weak for $36 \%$ and very weak for $3 \%$ accession. Strong and moderately strong culms are beneficial for rice production as it reduces lodging as well as yield losses.

Type of axis and panicle, panicle exertion, secondary branching and awn

It was found that $32 \%$ germplasm had straight axis whereas $68 \%$ had droopy type. Similar trait was also studied (74) who also found droopy axis in most of their studied genotypes. Among the tested germplasm, $87 \%$ accessions had intermediate type of panicle and only $13 \%$ had open panicle. None of them had compact type of panicle. About 36\% germplasm with moderately well exerted panicle followed by $32 \%$ with just exerted panicles, $26 \%$ with partly exerted panicles and 6\%with well exerted panicles. Variation was found for panicle exertion as it is affected by the agroclimatic condition and cropping seasons of this crop (73, 76). Well exerted panicle is more advantageous than other types as it helps in successful pollination which is a must for higher yield in rice. Of the studied germplasm, 77\% had light secondary branching. Only $19.36 \%$ germplasm possessed awn at grain $(80.645 \%)$. Similar work was also reported (69). Earlier reports were also showed a wider variability for this trait (71). Awn at tip was found for $13 \%$ germplasm and $3.23 \%$ for each upper quarter and upper three quarters. Rice having awn at grain helps it to survive in the changing environment.

\section{Lemma and palea pubescence, endosperm type, leaf senescence, shattering and threshability}

Among the studied germplasm, 71\% showed glabrous pubescence of lemma and palea followed by $19 \%$ short hairs and $10 \%$ hairs on upper portion. The thickness of pubescence of lemma plays a very important role in identification of different varieties of rice (77). Majority of the germplasm possessed glutinous type of endosperm $(74 \%)$ while $7 \%$ had non-glutinous or nonwaxy type (6\%) and $19 \%$ had the intermediate type. Out of the studied rice germplasm, 36\% germplasm expressed very early leaf senescence, 26\% late and slow, $16 \%$ of each intermediate and very late and $6 \%$ early leaf senescence. Shattering was very low in most of the selected germplasm accessions (64\%) which is very helpful for reducing post-harvest loss of rice as it reduces the shed of grain. Rest of the accessions had low (26\%) and moderate shattering (10\%). Regarding threshability, 58\% germplasm showed intermediate type of threshability followed by $13 \%$ moderately difficult, $13 \%$ loose, $13 \%$ easy and $3 \%$ difficult type of threshability. Rice germplasm having easy type of threshability is desirable as it reduces the post harvest loss of rice making the grain separation easy from its plant. High variability for threshability was also reported in rice $(58,72)$.

\section{Conclusion}

Exploration and documentation of phenotype information is a priority research need in crop modeling, breeding, for association studies, gene discovery, choosing cultivars and planning crosses for maximizing genetic gain. To the best of our knowledge, the current study is the first phenotypic study involving yield and yield contributing traits including DUS traits and genetic analyses of the traits by utilizing the local rice germplasm. Significant variability and diversity were observed among the studied rice genotypes for both qualitative and quantitative traits. Among the studied genotypes, Sentu-16 was the highest yielding that can be used in future plant breeding program. Selection of the traits such as number of effective tillers/hill, number of filled grains/panicle and 1000-grain weight might be effective to improve grain yield in rice as these traits had high heritability coupled with high GA (\%) and positive significant relationship with grain yield/plant. Maximum genetic diversity was found among the 
genotypes included in cluster II and cluster V and selection of these genotypes might give rise to high heterotic response in the segregating generation. The traits such as blade color, leaf angle, flag leaf angle, culm angle, internode color, culm strength, panicle exertion, shattering, threshability, apiculus color, stigma color, lemma and palea color, lemma and palea pubescence, sterile lemma color, seed coat color and leaf senescence found as suitable traits which might be used for further improvement of rice. Finally, the findings of the study open-up new horizon for developing high yielding Aman rice varieties by utilizing promising genotypes and trait associations.

\section{Acknowledgements}

Authors gratefully acknowledge the financial support provided by Ministry of Science and Technology, Government of the People's Republic of Bangladesh.

\section{Authors' contributions}

$\mathrm{AKH}$ and FY came up with the idea and designed the experiments. FRE and $\mathrm{HK}$ also take part in designing the experiment. FRE and HK carried out the experiment and recorded the data. FR Emi prepared the initial manuscript and HK rearranged it discussing with MAH and AKH. MAH, AKH and FY critically read the manuscript and revised accordingly. MAH did the proof-reading of the final draft. All authors helped to finalize the manuscript and gave approval for submission of the final manuscript after critical assessment.

\section{Compliance with ethical standards}

Conflict of interest: The authors declare that they have no competing interests.

Ethical issues: None.

\section{References}

1. Shelley I, Takahashi-Nosaka M, Kano-Nakata M, Haque M, Inukai Y. Rice cultivation in Bangladesh: present scenario, problems and prospects: a review. J Int Coop Agri Dev. 2016;14:20-29.

2. Ahmed MS, Rashid ESMH, Akter $\mathrm{N}$ and Khalequzzaman $\mathrm{M}$. Morphological characterization and diversity of T. Aman rice germplasm of Bangladesh. Bangladesh Rice J. 2020;22(2):13-22. https://doi.org/10.3329/brj.v22i2.44038

3. Haque MM, Majumder RR, Hore TK, Biswash MR. Yield contributing characters effect of submerged water levels of Boro Rice (Oryza sativa L.). Scientia. 2015;9(1):23-29. https://doi.org/10.15192/PSCP.SA.2015.9.1.2329

4. FAOSTAT. FAO Statistical Yearbook. Food and Agricultural Organization of the United Nations, FAO, Rome, Italy; 2016.

5. BBS. The year book of agricultural statistics of Bangladesh. Statistical Division, Ministry of Planning, Government of People’s Republic of Bangladesh, Dhaka. 2018;123-27.

6. Tang SX, Jiang YZ, Wei XH, Li ZC, Yu HY. Genetic diversity of isozymes of cultivated rice in China. Acta Agron Sin. 2002;28:203-07.

7. Dutta RK, Lahiri BP, Mian MA. Characterization of some aromatic and fine rice cultivars in relation to their physico- chemical quality of grains. Indian J Plant Physiol. 1998;3(1):6164.

8. IRRI. Scuba rice: breeding flood tolerance to Asia's local mega rice varieties. International Rice Research Institute, Los Banos, Philipines; 2010.

9. Hasan MJ, Rahman MH, Akter A, Kulsum MU, Islam A. Assessment of appropriate doses of GA3 and row ratio for better seed yield of a promising hybrid rice variety. Bangladesh Rice J. 2015;19(1):49-53. https://doi.org/10.3329/brj.v19i1.25221

10. Siddiq EA 2002: Exploiting means to adapt GM rice. The Hindu Survey of Indian Agriculture. Kasturi and Sons Limited, Chennai; 2002. p.47-52.

11. Islam N, Kabir MY, Adhikary SK, Jahan MS. Yield performance of six local aromatic rice cultivars. Scholars J Agric Vet Sci. 2013;6(3):58-62. https://doi.org/10.9790/2380-0635862

12. Akhtar N, Nazir MF, Rabnawaz A, Mahmood T, Safdar ME, Asif $\mathrm{M}$ et al. Estimation of heritability, correlation and path coefficient analysis in fine grain rice (Oryza sativa L.). J Anim Plant Sci. 2011;21(4):660- 64

13. Ahmadizadeh M, Nori A, Shahbazi H, Aharizad S. Correlated response of morpho-physiological traits of grain yield in durum wheat under normal irrigation and drought stress conditions in greenhouse. Afr J Biotechnol. 2011;10(85):19771-79. https://doi.org/10.5897/AJB11.2371

14. Ndour D. Tests of agro-morphological characterization and genetics of salt tolerance in rice (Oryza sativa L.) in the Senegal River Delta. Memory Master II. Dakar: University; 1998. p. 1-27.

15. Johnson HW, Robinson HF, Comstock RE. Estimates of genetic and environmental variability in soybeans. J Agron. 1955;47: 314-18. https://doi.org/10.2134/agronj1955.00021962004700070009x

16. Singh DN, Sahu A, Parida AK. Genetic variability and correlation studies in tomato (Solanum lycopersicum). J Environ Ecol. 1997;15:135-41.

17. Comstock RE, Robinson HF. Genetic parameters, their estimation and significance. Proceedings of the Sixth International Grassland Congress 1; 1952. p. 284-91.

18. Singh RK, Choudhury BD. Biometrical method in quantitative genetic analysis. Kalyani Publishers, Ludhiana, New Delhi, India; 1985 . p. 318.

19. Bhadru D, Rao VT, Mohan YC, Bharathi D. Genetic variability and diversity studies in yield and its component traits in rice (Oryza sativa L.). J Breed Genet. 2012;44(1):129-37.

20. Chakravorty A, Bhaumik S, Ghosh A. Studies on variability and interrelationship of panicle components and their association with grain yield in traditional rice. IOSR J Pharm Biol Sci. 2012;2(5):35-40. https://doi.org/10.9790/3008-0253540

21. Sumanth V, Suresh BG, Ram BJ, Srujana G. Estimation of genetic variability, heritability and genetic advance for grain yield components in rice (Oryza sativa L.). J Pharmacognosy and Phytochem. 2017;6(4):1437-39.

22. Haque M, Biswas MR. Characterization of commercially cultivated hybrid rice in Bangladesh. World J Agric Sci. 2014;10(6):300-07.

23. Sarkar SC. Performance of five selected hybrid rice varieties in Aman season. MS Thesis. Dhaka: Sher-E-Bangla Agricultural University; 2014.

24. Saha SR. Morpho-molecular and grain quality characterization of rice landraces. MS Thesis. Mymensingh: Bangladesh Agricultural University; 2018.

25. Shahriar MH. Morphological characterization and SSR-based molecular screening of advanced breeding lines of transplanted Aman rice for short growth duration. MS thesis. Mymensingh: Bangladesh Agricultural University; 2014.

26. Patnaik SSC, Mohanty SK. Improving productivity of rain-fed, shallow favorable lowland and irrigated rice production system. CRRI Annual Report; 2006. p. 17.

27. Marambe B. Properties of rice growing in abandoned paddies in Sri Lanka. In: Gressel J, editor. Crop Ferality and Volunterism. Sri Lanka; $2005 . \quad$ p. 295-303. https://doi.org/10.1201/9781420037999.ch18 
28. Saha R. Study of agronomic efficiency and recovery efficiency of urea super granule on transplanted Aman rice. MS Thesis. Mymensingh: Bangladesh Agricultural University; 2013.

29. Hoque A. Morpho-physiological and molecular characterization of rice (Oryza sativa L.) advanced breeding lines for earliness. MS Thesis. Mymensingh: Bangladesh Agricultural University; 2013.

30. Riba UST. Characterization of jhum rice (Oryza sativa L.) germplasm through morpho-molecular approaches. MS Thesis. Mymensingh: Bangladesh Agricultural University; 2018.

31. Ranawake AL, Amarasingha UGS, Dahanayake N. Agronomic characters of some traditional rice (Oryza sativa L.) cultivars in Sri Lanka. Ruhuna J Sci. 2013;1(1):3-9. https://doi.org/10.4038/jur.v1i1.6150

32. Hasanuzzaman M, Hossain MA, Teixeira da Silva JA, Fujita M. Plant responses and tolerance to abiotic oxidative stress: antioxidant defenses is a key factors. In: V Bandi, AK Shanker, C Shanker, M Mandapaka, editors. Crop Stress and Its Management: Perspectives and Strategies. Springer, Berlin, Germany; 2008. p. 261-316. https://doi.org/10.1007/978-94-0072220-0_8

33. Ashfaq M, Khan AS, Khan SHU, Ahmad R. Association of various morphological traits with yield and genetic divergence in rice (Oryza sativa L.). Int J Agric Biol. 2012;14:55-62.

34. Khanam AA. Characterization and comparative assessment of ten advanced lines of Aus rice (Oryza sativa L.). MS Thesis. Dhaka: Sher-E-Bangla Agricultural University; 2018.

35. Bose LK, Pradhan SK. Genetic divergence in deep water rice genotypes. Eur J Control. 2005;6(4):635-40.

36. Joshi MA, Sarao NK, Sharma RC, Singh P, Bharaj TS. Varietal characterization of rice (Oryza sativa L.) based on morphological descriptors. Seed Sci Res. 2007;35(2):188-93.

37. Rahman AKMH, Islam MM, Nadim MKA, Akter SE, Alim SMA and Noor MMA. Genetic variability analysis of different yield contributing characters of cultivated T. Aman rice (Oryza sativa) varieties. J Biosci Agric Res. 2021;27(01):2258-66.

38. Rashmi D, Saha S, Loitongbam B, Singh S, Singh PK. Genetic variability study for yield and yield components in rice (Oryza sativa L.). Int J Agric Environ Biotechnol. 2017;10(2):171-76. https://doi.org/10.5958/2230-732X.2017.00020.1

39. Sanghera GS, Kashyap SC. Genetic parameters and selection indices in F3 progenies of hill rice genotypes. Not Sci Biol. 2012;4(4):110-14. https://doi.org/10.15835/nsb448275

40. Edukondalu B, Reddy VR, Rani TS, Kumari CA, Soundharya B. Studies on variability, heritability, correlation and path analysis for yield, yield attributes in rice (Oryza sativa L.). Int J Curr $\begin{array}{llll}\text { Microbiol Appl } & \text { Sci. } & \text { 2017;6(10):2369-76 }\end{array}$ https://doi.org/10.20546/ijcmas.2017.610.279

41. Gour L, Koutu GK, Singh SK, Patel DD, Shrivastava A, Singh Y. Genetic variability, correlation and path analysis for selection in elite breeding materials of rice (Oryza sativa L.) genotypes in Madhya Pradesh. J Pharma Innov. 2017;6(11):693-96.

42. Srujana G, Suresh BG, Lavanya GR, Ram BJ, Sumanth V. Studies on genetic variability, heritability and genetic advance for yield and quality components in rice (Oryza sativa L.). J Pharmacognosy and Phytochem. 2017;6(4):564-66.

43. Chakravorty A, Ghosh PD, Sahu PK. Multivariate analysis of phenotypic diversity of landraces of rice of West Bengal. Am J Exp Agric. https://doi.org/10.9734/AJEA/2013/2303

44. Vanisree S, Swapna K, Raju CD, Raju CS, Sreedhar M. Genetic variability and selection criteria in rice. J Biol Sci Opinion 2013;1(4):341-46. https://doi.org/10.7897/2321-6328.01413

45. Babu VR, Shreya K, Dangi KS, Usharani G, Nagesh P. Genetic variability studies for qualitative and quantitative traits in popular rice (Oryza sativa L.) hybrids of India. Int J Sci Res. 2012;2(6):1-5.

46. Pandey VR, Anurag J. Estimation of genetic parameters in indigenous rice. Adv Agric Bot. 2010;2(1):79-84.

47. Subbaiah PV, Sekhar MR, Reddy KHP, Reddy NPE. Variability and genetic parameters for grain yield and its components and kernel quality attributes in CMS based rice hybrids (Oryza sativa L.). Int J Appl Biol Pharm. 2011;2:603-09.

48. Kalyan B, Krishna KVR, Rao LVS. Correlation coefficient analysis for yield and its components in rice (Oryza sativa L.) genotypes. Int J Curr Microbiol Appl Sci. 2017;6(7):2425-30. https://doi.org/10.20546/ijcmas.2017.607.287

49. Sameera S, Srinivas T, Rajesh AP, Jayalakshmi V, Nirmala PJ. Variability and path coefficient for yield and yield components in rice. Bangladesh J Agric Res. 2016;41(2):259-71. https://doi.org/10.3329/bjar.v41i2.28229

50. Reddy GE, Suresh BG, Sravan T, Reddy PA. Interrelationship and cause-effect analysis of rice genotypes in North East plain zone. The Bioscan. 2013;8(4):1141-44.

51. Kumar S, Chauhan MP, Tomar A, Kasana RK, Kumar N. Correlation and path coefficient analysis in rice (Oryza sativa L.). J Pharma Innov. 2018;7(6):20-26.

52. Lakshmi VM, Suneetha Y, Yugandhar G, Lakshmi VN. Correlation studies in rice (Oryza sativa L.). J Genet Eng Biotechnol. 2014;5(2):121-26.

53. Akhi AH, Miah MAK, Ivy NA, Islam A, Islam MZ. Association of yield and yield related traits in aromatic rice (Oryza sativa L.) Bangladesh J Agric Res. 2016;41(3):387-96. https://doi.org/10.3329/bjar.v41i3.29710

54. Ratna M, Begum A, Husna A, Dey SR, Hossain MS. Correlation and path coefficients analysis in basmati rice. Bangladesh J Agric Res. 2015;40(1):153-61. https://doi.org/10.3329/bjar.v40i1.23768

55. Patel JR, Saiyad MR, Prajapati KN, Patel RA, Bhavani RT. Genetic variability and character association studies in rain-fed upland rice (Oryza sativa L.). Electron J Plant Breed. 2014;5(3):531-37.

56. Devi KR, Chandra BS, Lingaiah N, Hari Y, Venkanna V. Analysis of variability, correlation and path coefficient studies for yield and quality traits in rice (Oryza sativa L.). $\begin{array}{lll}\text { Agric Sci } & \text { Digest. } & \text { 2017;37(1):1-9. }\end{array}$ https://doi.org/10.18805/asd.v0iOF.7328

57. Manikyaminnie C, Reddy DT, Raju CS. Correlation and path analysis for yield and its components in rice (Oryza sativa L.). J Sci Res. 2013;41(1):132-34. https://doi.org/10.5958/0975928X.2018.00076.5

58. Islam MZ, Akter N, Chakrabarty T, Bhuiya A, Siddique MA, Khalequzzaman M. Agro-morphological characterization and genetic diversity of similar named aromatic rice (Oryza sativa L.) landraces of Bangladesh. Bangladesh Rice J. 2018;22(1):45-56. https://doi.org/10.3329/brj.v22i1.41836

59. Ma M, Meng H, Wang T, Lu B. Phenotype diversity analysis of red-grained rice landraces from Yuanyang Hani's terraced fields. In: AIP Conference Proceedings; Shanghai, China; 2017. p. 1890:040110. https://doi.org/10.1063/1.5005312

60. Maji AT, Shaibu AA. Application of principal component analysis for rice germplasm characterization and evaluation. J Plant Breed Crop Sci. 2012;4(6):87-93. https://doi.org/10.5897/JPBCS11.093

61. Yugandhar PR, Kota S, Kiran BU, Sridhar M. Principal component analysis for agro-morphological and quality characters in germplasm of rice (Oryza sativa L.). Int J Adv Biol Res. 2018;8(2):268-73.

62. Gour L, Maurya SB, Koutu GK, Singh SK, Shukla SS, Mishra DK. Characterization of rice (Oryza sativa L.) genotypes using principal component analysis including scree plot and rotated component matrix. Int J Chem Stud. 2017;5(4):975-83.

63. Ojha GC, Sarawgi AK, Sharma B, Parikh M. Principal component analysis of morpho-physiological traits in rice germplasm accessions (Oryza sativa L.) under rainfed condition. Int J Chem Stud. 2017;5(5):1875-78.

64. Khatun MT, Hanafi MM, Rafii YM, Wong MY, Salleh FM, Ferdous J. Genetic variation, heritability and diversity analysis of upland rice (Oryza sativa L.) genotypes based on quantitative traits. Intal J Biol Medical Res. 2015;5(1):122-30. https://doi.org/10.1155/2015/290861 
65. Sinha AK, Mishra PK. Agro-morphological characterization and morphology based genetic diversity analysis of landraces of rice variety (Oryza sativa L.) of Bankura district of West Bengal. Int J Curr Res. 2013;5(10):2764-69.

66. Maurya BK, Singh PK, Verma OP, Mandal DK. Genetic variability and divergence analysis in rice (Oryza sativa L.) under sodic soil. Int J Curr Microbiol Appl Sci. 2017;6(10):2865-69. https://doi.org/10.20546/ijcmas.2017.610.336

67. Ashok S, Jyothula DPB, Ratnababu D. Genetic divergence studies for yield, yield components and grain quality parameters in rice (Oryza sativa L.). Electron J Plant Breed. 2017;8(4):1240-46. https://doi.org/10.5958/0975-928X.2017.00178.8

68. Ahmed MS, Parveen S, Bashar MK, Shamsuddin AKM. Genetic divergence of balam rice (Oryza sativa L.) germplasm of Bangladesh. Bangladesh Rice J. 2015;19(1):9-14. https://doi.org/10.3329/brj.v19i1.25214

69. Parikh M, Motiramani NK, Rastogi NK, Sharma B. Agromorphological characterization and assessment of variability in aromatic rice germplasm. Bangladesh J Agric Res. 2012;37(1):18. https://doi.org/10.3329/bjar.v37i1.11168

70. Moukoumbi YD, Sié M, Vodouhe R, N'dri1 B, Toulou B, Ogunbayo SA et al. Assessing phenotypic diversity of interspecific rice varieties using agro-morphological characterization. J Plant Breed Crop Sci. 2011;3(5):74-86.

71. Mehla BS, Kumar S. Use of morphological traits as descriptors for identification of rice genotype. Agric Sci Digest. 2008;28(2):104.

72. Sarawgi AK, Parikh M, Sharma B, Sharma D. Phenotypic divergence for agro-morphological traits among dwarf and medium duration rice germplasm and inter-relationship between their quantitative traits. J Plant Breed Genet 2014;1677-81.

73. Chakravorty A, Ghosh PD. Characterization of landraces of rice following DUS guidelines. Res Plant Biol. 2012;2(6):30-40.
74. Manjunatha GA, Elsy CR, Rajendran P, Joseph J, Francies RM, Krishnan S. DUS characterization of rice (Oryza sativa L.) landraces of Wayanad, Kerala. Electronic J Plant Breed. 2018;9(2):617-30. https://doi.org/10.1201/9781420037999.ch18

75. Pragnya K, Krishna RKV, Rao LVS, Suneetha K. Studies on morphological characterization in soft rice (Oryza sativa L.) genotypes. Int J Curr Microbiol Appl Sci. 2018;7(5):1348-74. https://doi.org/10.20546/ijcmas.2018.705.162

76. Hoan NT, Kinh NN, Bang BB, Tram NT, Qui TD, Bo NV. Hybrid Rice Research and Development in Vietnam. In: SS Virmani, EA Siddiq, Muralidharan, editors. Advances in Hybrid Rice Technology. 1998. p. 325-41.

77. Bora R, Deka SD, Sen P. Identification of rice varieties of Assam based on grain characters and reaction to certain chemical tests. Seed Sci Res. 2008;36(1):51-55.

\section{Additional information}

Peer review information: Plant Science Today thanks Sectional Editor and the other anonymous reviewers for their contribution to the peer review of this work.

Reprints and permissions information is available at https://horizonepublishing.com/journals/index.php/PST/open_access_policy

Publisher's Note: Horizon e-Publishing Group remains neutral with regard to jurisdictional claims in published maps and institutional affiliations.

To cite this article: Emi $F \mathrm{R}$, Khatun $\mathrm{H}$, Yasmine $\mathrm{F}$, Hasan $\mathrm{A} \mathrm{K}$, Hossain $\mathrm{M} \mathrm{A}$. Morphological variability and genetic diversity of Aman rice germplasm of Bangladesh cultivated in Mymensingh region. Plant Science Today. 2021;8(4):972-985. https://doi.org/10.14719/pst.1304

Plant Science Today, published by Horizon e-Publishing Group, is covered by Scopus, Web of Science, BIOSIS Previews, Clarivate Analytics, etc. See https://horizonepublishing.com/journals/index.php/PST/indexing_abstracting 